\title{
NEW PLEISTOCENE VERTEBRATE FAUNA FROM EL SALVADOR
}

\author{
JUANCARLOS CISNEROS \\ Bernard Price Institute for Palaeontological Research, University of the Witwatersrand, Private Bag 3, WITS 2050, Johannesburg, \\ South Africa.JC_Cisneros@hotmail.com
}

\begin{abstract}
The discovery of an Early-Middle Pleistocene continental vertebrate fauna from El Salvador is here reported. These fossils provide information about a poorly studied geographic area that played an important role during the Great American Faunal Interchange. The fauna is dominated by numerous remains of the proboscidean Cuvieronius tropicus and probably represents the largest known concentration of this genus in America. A number of living taxa are first recorded as fossils in El Salvador, including Crocodylus acutus, previously unknown as a fossil elsewhere. Hesperotestudo crassiscutata, Glyptotherium arizonae, Palaeolama, Hemiauchenia cf. H. seymourensis and Equus conversidens, are recorded for the first time in Central America. The new locality also holds the oldest record of Mazama, and the southernmost records of Glyptotherium arizonae and Equus conversidens. At least 17 taxa are represented in the new site, constituting the richest Central American continental vertebrate locality hitherto known.
\end{abstract}

Key words: Mammals, El Salvador, Central America, Pleistocene, Great American Faunal Interchange.

RESUMO - Reporta-se o achado de uma fauna Eo-Mesopleistocênica de vertebrados em El Salvador. Os fósseis aportam informações sobre uma área geográfica pouco estudada que teve um papel relevante durante o Grande Intercâmbio Faunístico Americano. A fauna é dominada por numerosos restos do proboscídeo Cuvieronius tropicus e representa, provavelmente, a maior concentração fossilífera deste gênero na América. São registrados como fósseis por vez primeira em El Salvador vários taxa vivos, entre eles Crocodylus acutus, do qual inexistem quaisquer registros fósseis prévios em outros países. São assinalados pela primeira vez para a América Central: Hesperotestudo crassiscutata, Glyptotherium arizonae, Palaeolama, Hemiauchenia cf. H. seymourensis e Equus conversidens. A nova localidade possui, também, o mais antigo registro de Mazama, e o mais austral de Glyptotherium arizonae e Equus conversidens. Pelo menos 17 taxa estão representados neste novo sítio, constituindo-se assim, na localidade de vertebrados continentais mais rica já conhecida na América Central.

Palavras-chave: Mamíferos, El Salvador, América Central, Pleistoceno, Grande Intercâmbio Faunístico Americano.

\section{INTRODUCTION}

Cenozoic vertebrate faunas in Central America are poorly represented in the fossil record, in spite of fossil outcrops being rather common in the area (Webb \& Perrigo, 1984). The search for fossils has been particularly limited. Local factors, including ongoing political strife and warfare in the last three decades, were a significant obstacle to carrying out palaeontological studies in the region. Nevertheless, the importance of Central America in the Neogene, due to its role as both a bridge and a filter during the Great American Faunal Interchange, and the need of extensive studies in the area are widely acknowledged (Stirton \& Gealey, 1949; Simpson, 1980;
Webb \& Perrigo, 1985; Lucas \& Alvarado, 1994; Webb 1991, 1997; Montellano Ballesteros, 1999). The area, acting as a filter, holds the southernmost and northernmost confirmed records for several widespread Plio-Pleistocene mammalian groups of both American continents, such as bovids, notoungulates, mammutids and elephantids (Howell, 1969; Webb \& Perrigo, 1984; Webb, 1991; Lucas \& Alvarado, 1991; Lucas et al., 1999); and was presumably an evolutionary centre for numerous groups that spread in both directions during the Great American Faunal Interchange. (Simpson \& de Paula Couto, 1956; Simpson, 1980; Gillette \& Ray; 1981; Webb \& Perrigo, 1984; Webb, 1991, 1997).

In 2000, a rich Pleistocene vertebrate locality was 
fortuitously discovered at the margins of Río Tomayate, north of San Salvador, El Salvador, by Teófilo Reyes. One year later, Reyes kindly donated the Cuvieronius molar found to the Museo de Historia Natural de El Salvador, and indicated the locality where he discovered it. Between April and August of 2001, the museum opened a quarry at the site, collecting a large number of proboscidean and other vertebrate remains, represented by more than a thousand field numbers. In 2002, the property was acquired by Salvadorian government and declared a national monument. The primary goal of this work is to provide a preliminary list of fauna of the new fossil site of Río Tomayate, which is probably the richest vertebrate locality hitherto found in Central America. Dental nomenclature follows in most part Smith \& Dodson (2003).

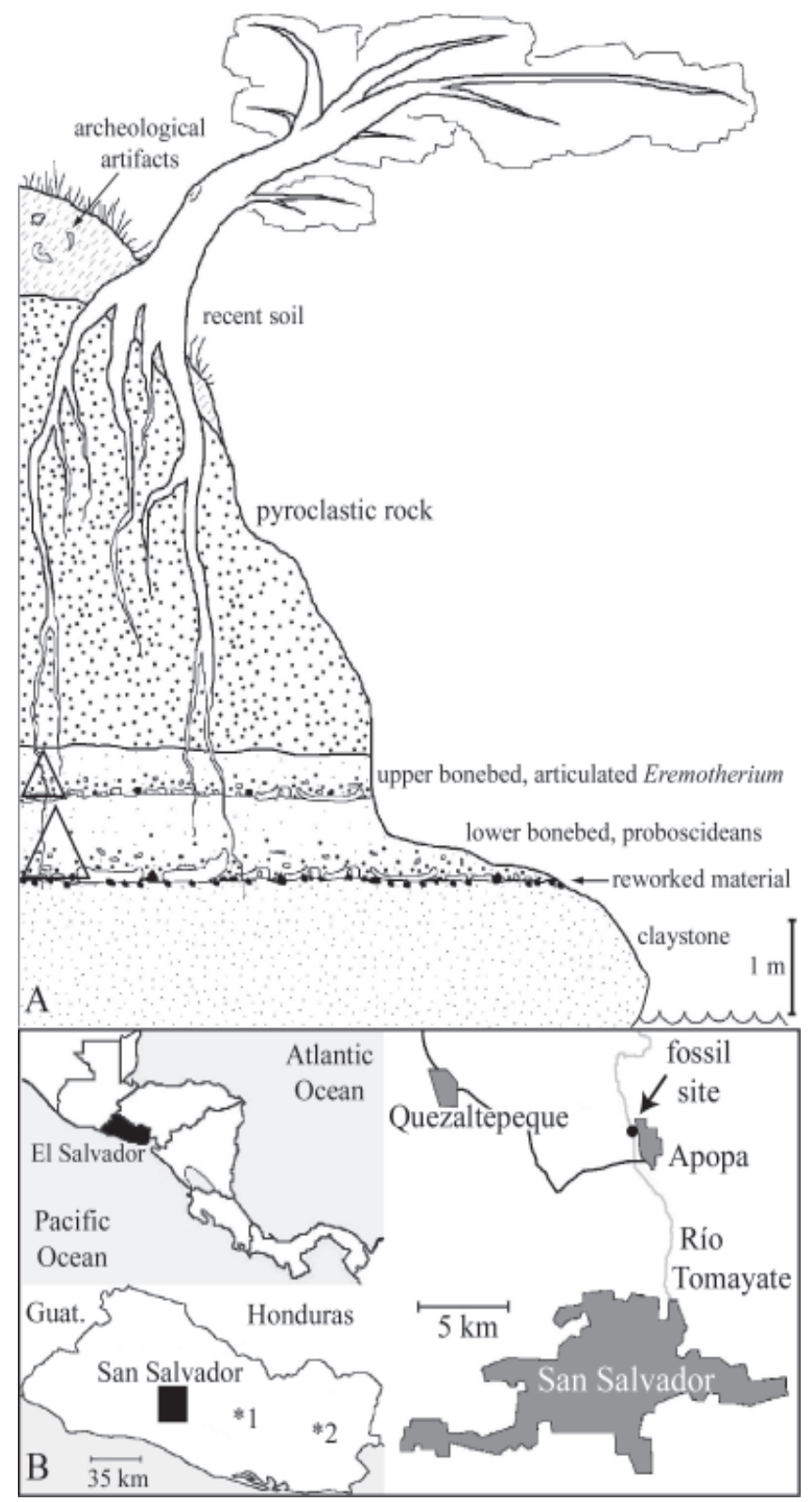

Figure 1. Simplified geologic section of the outcrop at Río Tomayate (A) with Fining upwards sequence $(\Delta)$ and reworked bones (in black). B, Location of the Tomayate outcrop and two other important Pleistocene localities from El Salvador: 1, Río Sisimico, Early-Middle Pleistocene; 2, El Hormiguero, Late Pleistocene.
Abbreviations. GAFI, Great American Faunal Interchange; NALMA, North American Land Mammal Age; SALMA, South American Land Mammal Age; MUHNES, Museo de Historia Natural de El Salvador.

\section{STUDY AREA}

The fossil site (Figure 1) is located at the margins of Río

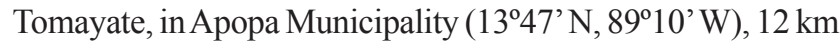
north from San Salvador, El Salvador. The outcrop is located approximately $3 \mathrm{~km}$ north from the Apopa-Quezaltepeque highway bridge over the river. Río Tomayate (known as Río Urbina within the city of San Salvador) is a small tributary of Río Acelhuate and both flow into the Río Lempa Basin. The river drains part of the city of San Salvador and the water is badly contaminated, and hygiene precautions are essential for collecting. No formal geological studies have been done in the work area, which is mostly covered with tropical vegetation that limits the outcrops available (Figure 2), making it difficult to carry out geological work on a regional scale. The river creates local outcrops that consist of a compact claystone locally known as "talpetate". At the fossil site, the claystone emerges at approximately $2 \mathrm{~m}$ from the water level of the river in the dry season. Unique to this exposure are two successive bonebeds that overlay the claystone stratum. The entire fossiliferous package has a lateral extent of about $50 \mathrm{~m}$ on both banks of the river, and is approximately $1.6 \mathrm{~m}$ thick. The matrix is a light brown unconsolidated ash with abundant pyroclasts and fragmentary fossil vegetal remains. Fossil collecting has been undertaken only at the eastern margin. All fossil vertebrates recovered are disarticulated, with one exception, a partial Eremotherium skeleton found in the upper bonebed. The vertebrates bear iron concretions, and recent disturbance by roots is rather common. Nevertheless, the state of preservation of the fossils is good. In each bonebed, the larger and heavier elements occur at the base, gradually decreasing in size towards the top, resulting in a fining upwards sequence. No sedimentary structures were recognized in the fossiliferous strata. The lower bonebed is approximately $0.9 \mathrm{~m}$ thick and the majority of the vertebrates were collected here. At the base of the lower bonebed, overlying the claystone, several weathered, subangular to subrounded, dense bones, are found. The latter elements have been reworked and should be older than the entire fossiliferous package, but it has been impossible to identify any of them due to their fragmentary state. The upper bonebed is approximately $0.7 \mathrm{~m}$ thick. The upper bonebed is overlain by a pyroclastic stratum of about $4 \mathrm{~m}$ in thickness, and is covered by a layer of modern soil that supports dense tropical vegetation. Archaeological artefacts are present in the soil and include pre-Hispanic ceramic and obsidian tools. Exposures of pyroclastic and epiclastic rocks of the Quaternary San Salvador Formation (Schmidt-Thomé, 1975), which are locally known as "tierra blanca", occur close to the site, but their relation with the fossiliferous packages is unclear. 


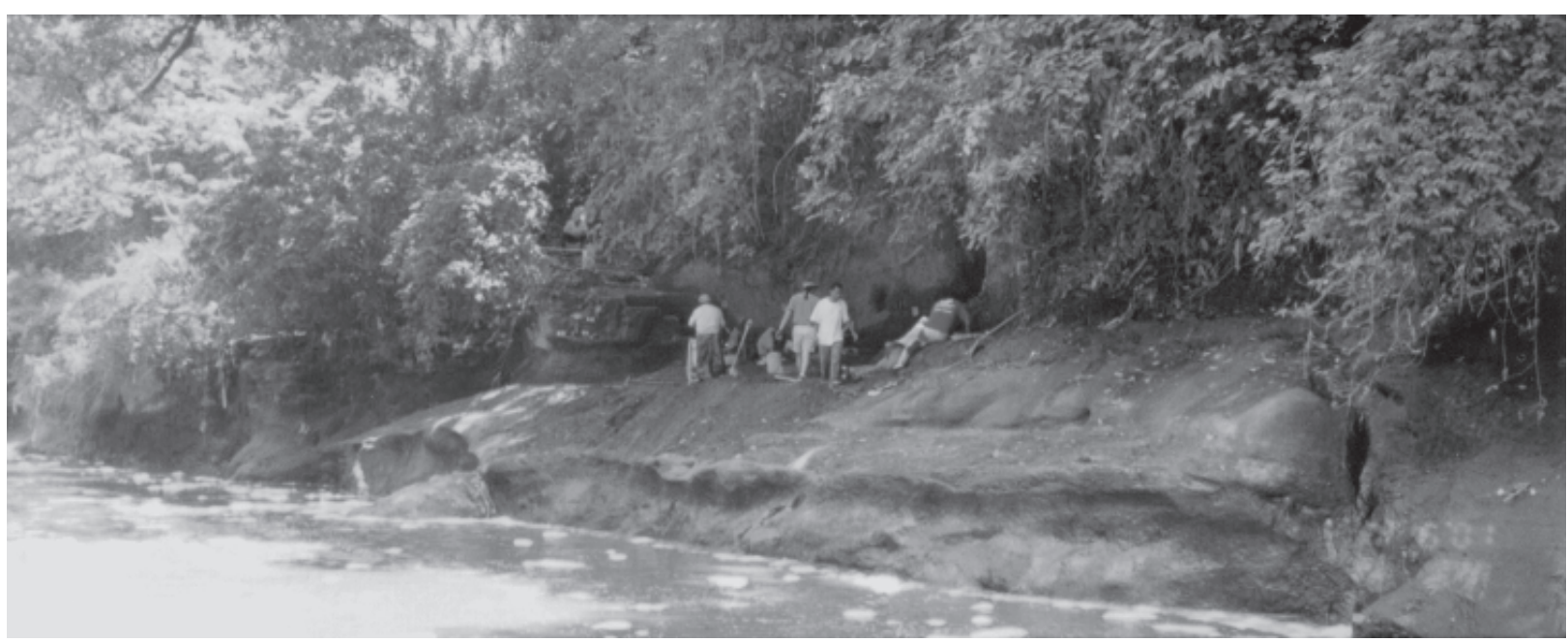

Figure 2. Photograph of the outcrop on the east shore of Río Tomayate.

\section{SYSTEMATIC PALAEONTOLOGY}

The vertebrate collection from Río Tomayate comprises several hundred specimens, a large number of which remain in plaster jackets or unprepared. This collection is being catalogued, and the numbers here provided are field numbers (preceded by 2 SSAP30 or 1SSAP6, field notation from MUHNES). For the sake of brevity, a sample of the most relevant specimens and brief descriptions emphasizing diagnostic characters are given here. These materials will be the subject of detailed descriptions to be provided elsewhere. All specimens are held at MUHNES, in San Salvador.

\section{TESTUDINES Linnaeus, 1758 \\ CRYPTODIRACope, 1868 \\ TESTUDINIDAE Batsch, 1788 \\ Hesperotestudo Williams, 1950 \\ Hesperotestudo crassiscutata Leidy, 1889}

(Figure 3C, D)

Referred material. 2SSAP30-205 shell fragment, 2SSAP30207 shell fragment, 2SSAP30-662 costal, 2SSAP30-675a, b shell fragments, 2SSAP30-790 costal and 2SSAP30-509 right xiphiplastron.

Description. Shell fragments remarkably large but noticeably thin and light build in relation to their size. Costals have relatively smooth ornamentation in the form of low longitudinal crests. 2SSAP30-509 is a right xiphiplastron with an obtuse posterior edge, indicating a shallow xiphiplastral notch. The anteroposterior length of the partial costal 2SSAP30-662 is $180-190 \mathrm{~mm}$, indicating a total carapace length of approximately $1.5 \mathrm{~m}$ for this individual. The exceptionally large size, smooth ornamentation and shallow xiphiplastral notch are characteristic of Hesperotestudo crassiscutata (Auffenberg, 1963).

Remarks. The shell fragments were not found in association and may represent different individuals. The genus name Hesperotestudo is used here instead of Geochelone following Meylan (2000). The only previous Hesperotestudo records in Central America come from the Lempira site (Late Miocene) in Honduras; and Río Sisimico (or Barranca del Sisimico, Early to Middle Pleistocene, ) and El Hormiguero (Late Pleistocene) in El Salvador (Webb \& Perrigo, 1984); none of these specimens has been identified at the species level.

\section{EMYDIDAE Rafinesque, 1815}

(Figure 3F)

Referred material. 2SSAP30-123 partial nuchal, 2SSAP30757 nuchal, 2SSAP30-758 right epiplastron.

Description. These nuchals lack the pronounced ornamentation present in members of the genus Trachemys, and could belong to either Pseudemys or Rhinoclemmys. The epiplastron possesses a gular scute overlap comprising less than half the bone surface, similar to Pseudemys. Unlike the latter, the anterior margin is not rounded, being more similar to that of Trachemys.

Remarks. The specimens represent the first report of fossil emydids from El Salvador. Disarticulated, chelonian shell fragments are among the most common remains recorded at Río Tomayate. Most of the specimens are probably emydid turtles, but poor preservation prevents positive identification at present.

\section{KINOSTERNIDAE Baur, 1893 \\ Kinosternon von Spix, 1824 \\ Kinosternon sp.}

(Figure 3E)

Referred material. 2SSAP30-229 left hyoplastron.

Description. This single plastral element is referred to Kinosternon due to its relatively elongated shape (but wider than Sternotherus) and the absence of a dorsally projected buttress. An unusual feature of this hyoplastron is the pronounced humeral scute overlap.

Remarks. This specimen constitutes the first report of the mud turtle Kinosternon as a fossil in Central America. 


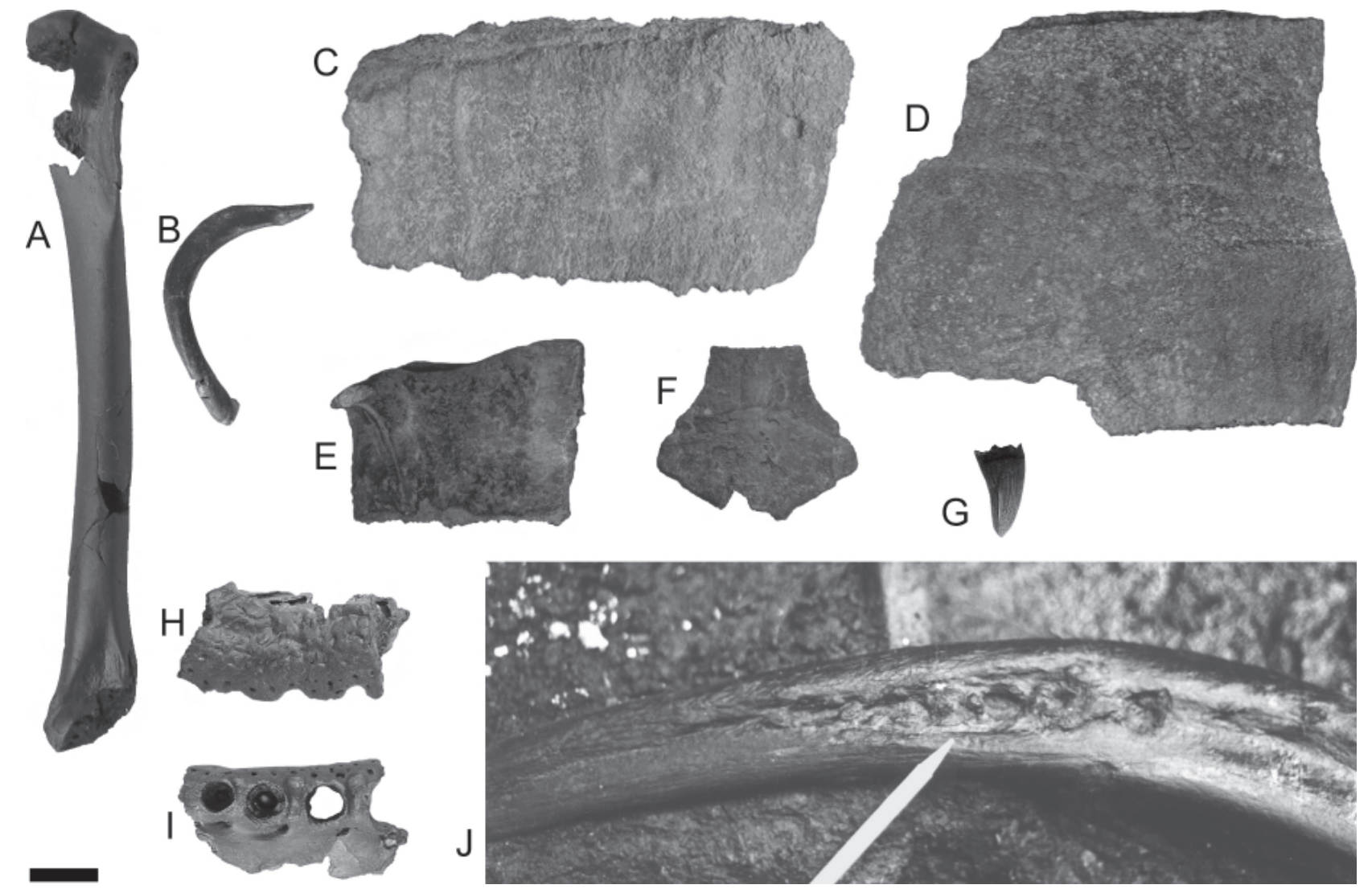

Figure 3. Testudines, crocodilians and birds from Río Tomayate. A, 2SSAP30-853 cf. Anser sp., left humerus in anterior (palmar) view; B, 2SSAP30-545 cf. Anser sp., left clavicle in lateral view; C, 2SSAP30-790 Hesperotestudo crassiscutata, costal in dorsal view; D, 2SSAP30-662 Hesperotestudo crassiscutata, costal, dorsal view; E, 2SSAP30-229, Kinosternon sp., left hyoplastron in dorsal view; F, Emydidae, genus indeterminate, nuchal in dorsal view; G, 2SSAP30-490 Crocodylus acutus, isolated tooth; H, I, 2SSAP30-676 Crocodylus acutus, left maxillary fragment in lateral and ventral view; J, 2SSAP30-807 in situ photograph of a probable proboscidean rib, bearing a crocodilian bite. Scale bar $=1.5 \mathrm{~cm}$ for $\mathrm{A}$ and $\mathrm{B} ; 2 \mathrm{~cm}$ for $\mathrm{E}-\mathrm{I}$; and $3 \mathrm{~cm}$ for $\mathrm{C}$ and $\mathrm{D}$. In $\mathrm{J}$, the pointing object is a common pencil.

\author{
EUSUCHIAHuxley, 1875 \\ CROCODYLIA Laurenti, 1768 \\ CROCODYLIDAE Cuvier, 1807 \\ Crocodylus Laurenti, 1768 \\ Crocodylus acutus Cuvier, 1807 \\ (Figure 3G-J)
}

Referred material. 2SSAP30-340, 2SSAP30-348, 2SSAP30481, 2SSAP30-490, 2SSAP30-499 incisive teeth; and 2SSAP30676 left maxillary fragment.

Description. 2SSAP30-676 is an anterior portion of a left maxilla from a mature specimen. There are three complete alveoli and the mesial portion of a fourth alveolus, separated by wide grooves (maximum length between first and third alveolus is $43 \mathrm{~mm}$ ). Although damaged, the fourth alveolus appears to be expanded and most likely, it accommodated the enlarged fifth maxillary tooth. Reposition teeth are preserved in the first and second alveoli. A number of isolated, non-associated teeth have also been recovered. They are long-crowned, slender and curved, from the anterior region of a cranium or mandible. Some osteoderms have also been recovered at the site. In addition, evidence of predatory or necrophagous activity by a crocodilian is shown by tooth marks on a probable proboscidean rib 2SSAP30-807. In this specimen, traces of at least seven large conical teeth are preserved. As in $C$. acutus, the interdental spaces of the maxilla 2SSAP30-676 are wider than in C. moreletti and C. rhombifer, but not as wide as in $C$. intermedius. The isolated teeth are more robust than in the latter, being compatible with those of $C$. acutus. Therefore, these remains are assigned to C. acutus. Remarks. There is only one unconfirmed report of fossil $C$. acutus, of Quaternary age, located outside the geographically known range of this species in Florida, USA (Neill, 1971; Meylan, 1995). These materials consisted of isolated teeth; hence, positive identification is not possible. Consequently, specimens from Río Tomayate constitute the first non-dubious fossil record of C. acutus, taking the lineage of this species back to the Pleistocene. These remains also constitute the first report of a fossil crocodilian from El Salvador. Only two other fossil crocodilian records are known from Central America: remains of C. moreletti were described by Mook (1959) from a poorly known Pleistocene locality at Santa Amelia, Petén, Guatemala; and an unidentified crocodilian reported for the Cucaracha Local Fauna of Early Miocene age of Panama by Whitmore \& Stewart (1965). 


\author{
AVES Linnaeus, 1758 \\ ANSERIFORMES Wagler, 1830 \\ ANATIDAE Leach, 1820 \\ Anser Linnaeus, 1758 \\ cf. Anser sp. \\ (Figure 3A, B)
}

Referred material. 2SSAP30-853 left humerus, 2SSAP30-545 left clavicle.

Description. The humerus is well-preserved. In the proximal head, the area from the capital groove to the bicipital crest is missing; in the distal head, only the entepicondylar prominence is present. Length is $164 \mathrm{~mm}$; width, at the level of the nutrient foramen, is $12 \mathrm{~mm}$. 2SSAP30-545 is an almost complete left clavicle found in association with the humerus, and is referred to the same individual. Considering the proportions and overall morphology of this humerus, it is provisionally assigned to the genus Anser.

Remarks. The specimens represent the first record of a fossil bird in El Salvador and the first fossil record of the genus Anser in Central America. Only one previous record of fossil birds is known in the region, the anatid Cairina moschata, recovered from El Hatillo, Panama, of Late Pleistocene age (Gazin, 1956).

\author{
MAMMALIA Linnaeus 1758 \\ XENARTHRACope, 1889 \\ CINGULATA Illiger, 1811 \\ GLYPTODONTIDAE Burmeister, 1879 \\ Glyptotherium Osborn, 1903 \\ Glyptotherium arizonae Gidley, 1926
}

(Figure 4A, B,G-J)

Referred material. 2SSAP30-510 second upper molariform, 2SSAP30-889 third upper molariform, and a large number of osteoderms.

Description. 2SSAP30-889 is a right third molariform (; max. measurements: meso-distal length $=19.9 \mathrm{~mm}$, labio-lingual length $=9.3 \mathrm{~mm}$ ), its mesial and distal occlusal borders are damaged, and also the lingual border of the second lobe. This tooth closely resembles the third molariform of $G$. arizonae in specimen UMMP 38761 from Gilliland, Texas, as depicted by Gillette \& Ray (1981, fig. 18a), though the Río Tomayate specimen possesses a less developed second lobe. 2SSAP30-510 is a left second molariform (maximum measurements: meso-distal length $=21.4 \mathrm{~mm}$, labio-lingual length $=8.4 \mathrm{~mm}$ ). This tooth is submolariform, its mesial and distal borders are slightly rounded, and the three lobes are less developed than in the reconstruction provided by Gillette \& Ray (1981, fig. 18a) based on the broken third molariform of specimen UMMP 34826 from Gilliland.

Approximately two hundred carapace fragments have been recovered at Río Tomayate. In most specimens, central figures are subcircular and somewhat larger than the peripherals, resembling Glyptotherium arizonae and G. cylindricum. In this respect, these scutes differ from those of G. texanum and G. mexicanum, in which the central figure is much larger than the peripherals, and from G. floridanum, in which the central figure and the peripherals are subequal in size (Gillette \& Ray, 1981). In scutes from the interior and lateral regions of the carapace, central figures are slightly elevated above the plane of peripheral figures with a smooth medial depression; and in scutes from the posterior region, the central figure is flattened. The morphology of interior and lateral scutes distinguish the Rio Tomayate material from G. cylindricum, where central figures are flattened or concave, therefore, making it possible to assign the new material to G. arizonae, in which interior and lateral scutes posses slightly convex central figures.

Remarks. The specimens represent the first record of Glyptotherium arizonae in Central America, and its southernmost occurrence. Glyptotherium remains were collected at both bonebeds in Río Tomayate, but are particularly abundant in the upper bonebed. It is possible that the osteoderms recovered at the upper bonebed and found in association with the molariform 2SSAP30-889, belong to a single individual, the remains of which could still be in situ. In addition, less diagnostic glyptodontid postcranial and fragmentary cranial material has been recovered at the lower bonebed. The genus Glyptotherium has also been reported for the Late Pleistocene localities of El Hormiguero, El Salvador; Yeroconte, Honduras; and El Hatillo, Panama (Gazin, 1956; Webb \& Perrigo, 1984) but none of the material has been identified at the species level.

PHYLLOPHAGA Owen, 1842
MEGATHERIIDAE Gray, 1821
Eremotherium Spillman, 1948
Eremotherium sp.
(Figure 4E, F, K)

Referred material. 1SSAP6-25 cranium and jaw. Partially articulated specimen: 2SSAP30-718, 720-722, 724 vertebral epiphyses; 2SSAP30-725-729, 735, 736, 750 vertebrae; 2SSAP30-730, 733, 751-755 ribs.

Description. A complete cranium and mandible of Eremotherium was recovered. Unfortunately, the cranium was badly damaged during transportation from MUHNES to Museo Nacional de Antropología. As a result, only the mandible is available for study. The overall morphology of this mandible is characteristic of Eremotherium, in particular the shallow tooth-bearing ramus, and the articular process that lies below the plane of the alveolar border (sensu de Iuliis \& Cartelle, 1999). A partially articulated adult individual was recovered in the upper bonebed; it is composed of an atlas and eight articulated cervical and thoracic vertebrae, with five associated ribs. This specimen remains in plaster jackets and it is the most complete individual of any taxon recovered at Río Tomayate.

Remarks. Eremotherium is a predominant taxon at Río Tomayate. In addition to the material listed here, several other fragmentary cranial and disarticulated postcranial remains have been collected, a large number of which are in plaster jackets or unprepared. In the lower bonebed, seven astragali were collected, indicating the presence of at least four individuals, a number than can be higher because some astragali are not completely 

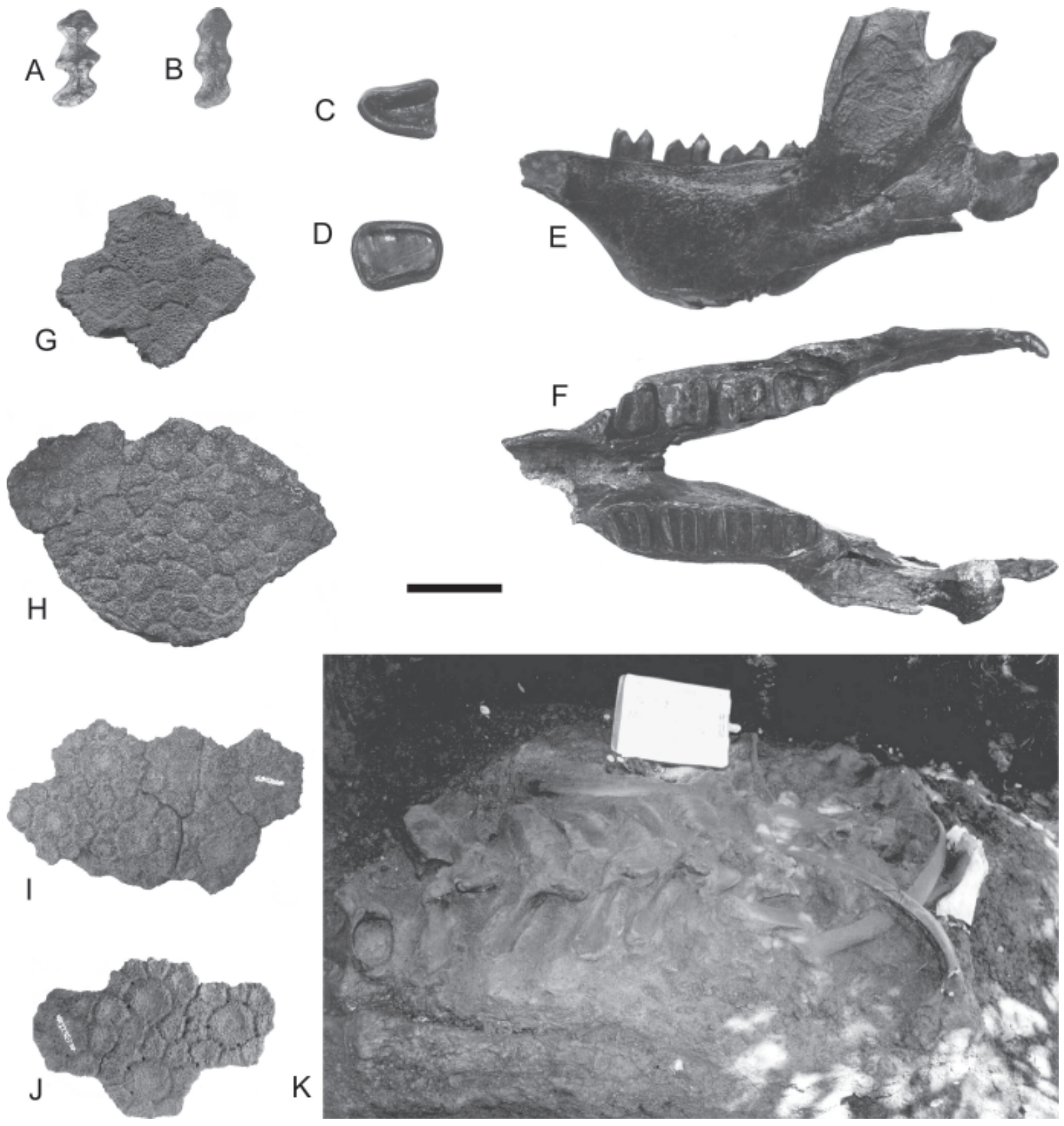

Figure 4. Xenarthrans from Río Tomayate. A, 2SSAP30-889 Glyptotherium arizonae, right third upper molariform in occlusal view; B, 2SSAP30-510 Glyptotherium arizonae, left second upper molariform in occlusal view; C, 2SSAP30-518 Megalonyx sp., right second molariform in occlusal view; D, 1SSAP6-65 Megalonyx sp. mandibular molariform in occlusal view; E and F, 1SSAP6-25 Eremotherium sp., mandible in left lateral and occlusal view; G, 2SSAP30-464 Glyptotherium arizonae, posterior carapace fragment; H, 2SSAP30-569 Glyptotherium arizonae interior carapace fragment; I, 2SSAP30-549 Glyptotherium arizonae lateral carapace fragment; J, MUHNES 70964 Glyptotherium arizonae lateral carapace fragment; K, in situ photograph of a partially articulated Eremotherium sp. found at the upper bonebed, 2SSAP30-718, 720-722, 724-730, 733, 735, 736, 750-755. Scale bar = $25 \mathrm{~mm}$ for A-D, $5 \mathrm{~m}$ for G-J, and $87.5 \mathrm{~mm}$ for E and F.

preserved, being difficult to orientate them. Taking into consideration the probable Early Pleistocene age of Río Tomayate fauna (see discussion), it is likely that these megatheriid remains belong to the recently described Late Blancan-Irvingtonian species E. eomigrans (de Iuliis \& Cartelle, 1999), since $E$. laurillardi seems to be restricted to the Late Pleistocene (Cartelle \& de Iuliis, 1995; de Iuliis \& Cartelle, 1999). Without conclusive morphological evidence, however, it is better not to assign this material to any particular species. Further study of the diagnostic features of the postcranial material in the collection (abundant postcranial material remains unprepared) may clarify the identity of the Río Tomayate megatheriid.

Eremotherium specimens have also been recovered in El Salvador at Río Sisimico and El Hormiguero localities (Webb \& Perrigo, 1984). Stirton \& Gealey (1949) collected several giant sloth specimens at El Hormiguero quarry, and assigned them to the genus Megatherium but these were later assigned to Eremotherium by Webb \& Perrigo (1984). 

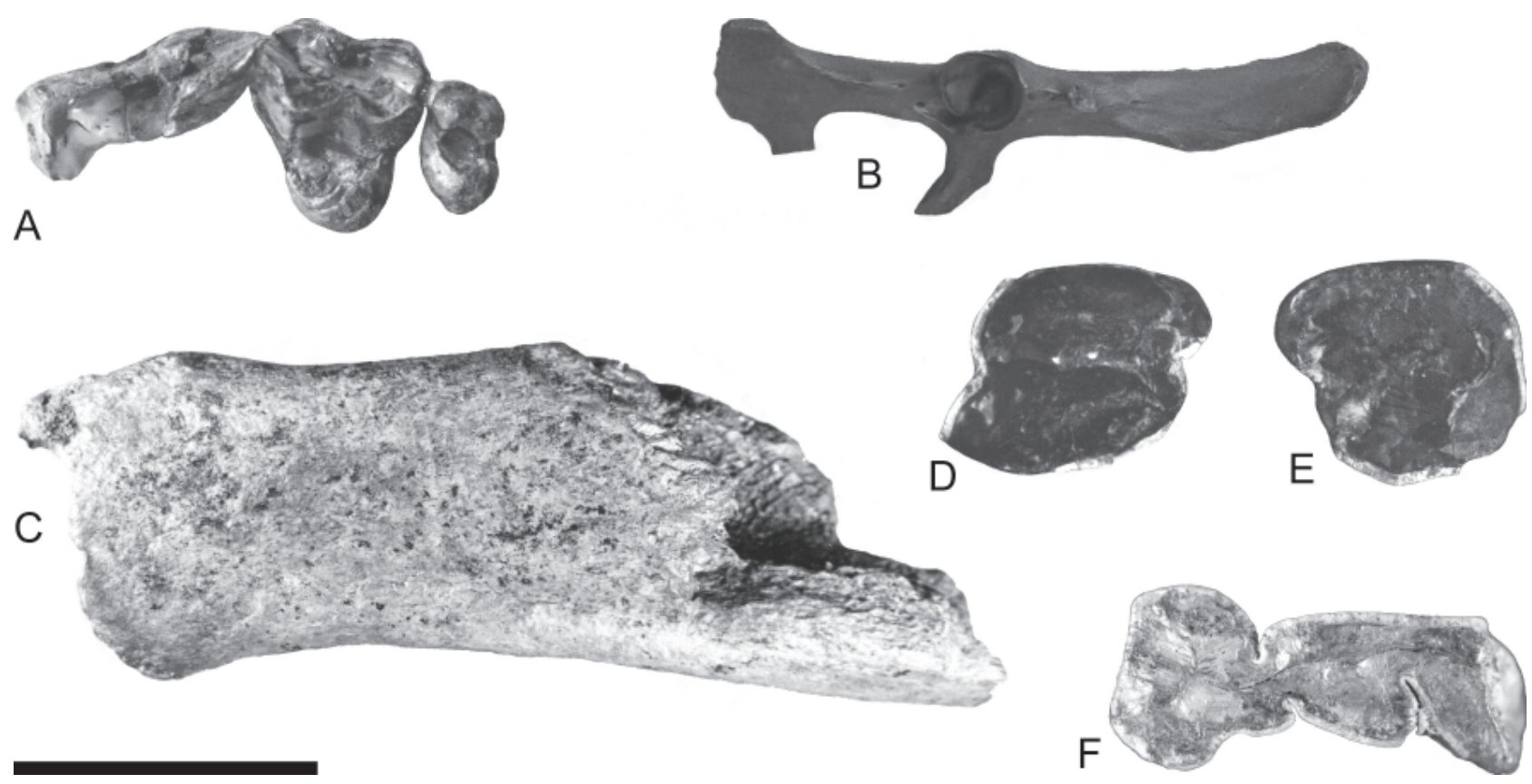

Figure 5. Canids, toxodontids and lagomorphs from Río Tomayate. A, 2SSAP30-734 aff. Canis, right maxilla in occlusal view; B, 1SSAP6174 Sylvilagus sp., right pelvis in lateral view; C, 2SSAP30-80 indeterminate bone with evidence of gnawing; D, 2SSAP30-610 Mixotoxodon larensis, LP3 in occlusal view; E, the same, in root view; F, 2SSAP30-157 Mixotoxodon larensis, Rm1 in occlusal view. Scale bar $=30 \mathrm{~mm}$ for A-B, D-F; and $60 \mathrm{~mm}$ for $\mathrm{C}$.

\author{
MEGALONYCHIDAE Gervais, 1885 \\ Megalonyx Harlan, 1825 \\ Megalonyx sp. \\ (Figure 4C, D)
}

Referred material. 1SSAP6-65 molariform, 2SSAP30-518 right second molariform.

Description. The teeth were not found in association. 2SSAP30-518 is a RM2, it is subtriangular in occlusal view and slightly recurved in labial view, its mesial border is convex and the distal border, concave (max. measurements: labiolingual length, $21.5 \mathrm{~mm}$; meso-distal length, $16 \mathrm{~mm}$ ). 1SSAP665 is trapezoid in occlusal view and slightly recurved (max. measurements: labio-lingual length, $24.2 \mathrm{~mm}$; meso-distal length, $8.3 \mathrm{~mm}$ ).

Remarks. Two melagonychids are known from El Salvador, Megalonyx obtusidens and Meizonyx salvadorensis (Webb \& Perrigo, 1985), both are endemic forms from Río Sisimico. The overall morphology of the specimens from Río Tomayate, however, precludes referring it to the primitive genus Meizonyx, which has no subtriangular or trapezoid teeth; or to Megalonyx obtusidens, in which all molariform teeth are ovoid in occlusal view. Although these specimens certainly belong to the genus Megalonyx, they are not diagnostic to the species level. Other Central American localities have yielded Megalonyx remains, all of Late Pleistocene age: El Bosque, Nicaragua (Page, 1978); Río Humuya, Honduras (Webb \& Perrigo, 1984) and Santa Amelia, Guatemala (Woodburne, 1969); none of these specimens were identified to species level.

\author{
LAGOMORPHA Brandt, 1855 \\ LEPORIDAE Gray, 1821 \\ Sylvilagus Gray, 1867 \\ Sylvilagus sp.
}

(Figure 5B)

Referred material. 1SSAP6-174 right pelvis.

Description. A well-preserved adult pelvis missing most of the pubis. It is distinguished from Brachylagus due to its larger size and from Lepus by a more slender ilium, a prominent posterior acetabular ridge and a thinner ischium with anteriorly expanded tuber ischii. Therefore, it is assigned to the cottontail rabbit, Sylvilagus.

Discussion. This Sylvilagus specimen represents the first record of a fossil lagomorph in El Salvador. At present, it is not possible to provide species-level identification based on a pelvis. The genus Sylvilagus has also been recorded at the Late Pleistocene site of Río Humuya, Honduras (Webb \& Perrigo, 1984).

\author{
CARNIVORA Bowdich, 1821 \\ CANIDAE Gray, 1821 \\ Canis Linnaeus, 1758 \\ aff. Canis sp. \\ (Figure 5A, C)
}

Referred material. 2SSAP30-734 partial left maxilla.

Description. This maxilla belongs to a large canid. It bears a P4, M1, and M2. P4 is damaged, lacking the surface of the mesial portion of the crown and all cusps. M1 is better 
preserved, but lacks the paracone and metacone cusps. M2 is the only entirely preserved element in the dental series. Maximum measurements: P4-M2 length, $52 \mathrm{~mm}$; P4 meso-distal length, $28.6 \mathrm{~mm}$; M1 meso-distal length, $18.8 \mathrm{~mm}$, labio-lingual length, $21.5 \mathrm{~mm}$; M2 meso-distal length, $8.3 \mathrm{~mm}$, labio-lingual length, $13.5 \mathrm{~mm}$. Unidentified long bones exhibiting evidence of gnawing, presumably by a canid, were also recovered at Río Tomayate.

Remarks. The overall morphology of the teeth suggests affinities with a large species within the genus Canis. The teeth are considerable bigger than in C. latrans, C. rufus and most $C$. lupus specimens; and suggest to the larger $C$. armbrusteri and $C$. dirus. The hypocone of the M1 in the Río Tomayate specimen, however, is reduced, in contrast to that in C. armbrusteri. Furthermore, the M2 of this specimen is very slender and mesodistally compressed. This condition differs from the species within the genus Canis, and resembles that of South American forms such as Theriodictis. It is not possible at this time to identify the Río Tomayate canid with any certainty based on this fragmentary material. The possibility that this specimen represents a new taxon cannot be discarded.

\section{NOTOUNGULATA Roth, 1903 \\ TOXODONTIDAE Owen, 1845 \\ Mixotoxodon van Frank, 1957 \\ Mixotoxodon larensis van Frank, 1957 \\ (Figure 5D-F)}

Referred material. 2SSAP30-157 lower molar, 2SSAP30-610 upper premolar, 2SSAP30-674b fragment of a lower molar. Description. The specimen 2SSAP30-157 is a well-preserved $\mathrm{Rm} 1$, lacking most of the root and a small portion of the hypoconid. Its maximum labio-lingual length, measured at the trigonid, is $18.5 \mathrm{~mm}$ and its maximum estimated mesio-distal length is $42 \mathrm{~mm}$. This tooth has an overall morphology compatible with Mixotoxodon, including the presence of a deep meta-entoconid fold, also seen in the holotype (van Frank, 1957, fig. 8a) from the Pleistocene of Venezuela, and in the Mixotoxodon cranium from the Lower Pleistocene of Costa Rica (Lucas et al., 1999, fig. 5a). The Río Tomayate specimen, however, differs in having a straighter labial margin of the talonid and a paraconid less developed meso-lingually than in the holotype (unfortunately the trigonid is not preserved in the Costa Rican specimen). The specimen 2SSAP30-610 is an LP3 almost indistinguishable from the P3 figured by van Frank (1957, fig. 9C), except for the presence in the former of a thin enamel band on the trigonid surface of the lingual fold. The absence of enamel in the lingual margin of the upper premolars is a diagnostic character of Mixotoxodon larensis (van Frank, 1957). The overall morphology of this P3 is, however, more similar to the $\mathrm{P} 3$ of Mixotoxodon than to the same element in Toxodon or any other well-known Pleistocene toxodontid. These materials are assigned to Mixotoxodon larensis despite minor, perhaps individual or geographical differences, observed in 2SSAP30-157 and 2SSAP30-610. 2SSAP30-674b is provisionally assigned to Mixotoxodon larensis due to its presence in the same outcrop, though these specimens were not found in association.

Remarks. In El Salvador, Mixotoxodon has been recorded in the Early to Middle Pleistocene Río Sisimico site (Webb \& Perrigo, 1984) and in the Late Pleistocene El Hormiguero site (van Frank, 1957). In Honduras, Mixotoxodon has been recorded in the Late Pleistocene sites of Yeroconte and Orillas del Humuya (Webb \& Perrigo, 1984), and in Costa Rica, at the Early Pleistocene Bajo Barrantes site (Laurito Mora, 1993; Lucas et al., 1999). From northern Nicaragua, Leidy (1886) described a Lm2 and a Ri3, collected at the Late Pleistocene Río El Chorro locality, which he assigned to the genus Toxodon. These teeth were discussed by van Frank (1957), who questioned Leidy's identification, particularly if the teeth were associated (information not provided by Leidy), which could allow Mixotoxodon affinity. The Nicaraguan molar (see van Frank, 1957, fig. 6a) is similar to 2SSAP30-157 if it is considered to be a $\mathrm{Lm} 1$ rather than a $\mathrm{Lm} 2$, which would support its assignment to Mixotoxodon. Another probable Nicaraguan toxodontid comes from the Late Pleistocene site of El Bosque (Espinoza Estrada, 1976; Page, 1978). The notoungulate mentioned by Woodburne (1969) from the Santa Amelia locality, Guatemala, must be a toxodontid. In La Coca, Panama, a toxodontid was referred to Toxodon by Gazin (1956), yet, because this discovery was prior to the proposal of the genus Mixotoxodon by van Frank (1957), it is likely that it is Mixotoxodon.

\section{PROBOSCIDEAIlliger, 1811 \\ PROBOSCIDEA Illiger, 1811 \\ GOMPHOTHERIIDAE Hay, 1922 \\ Cuvieronius Osborn, 1923 \\ Cuvieronius tropicus (Cope, 1884)}

(Figure 6)
Referred material. 2SSAP30-44 and 45 complete mandible; 2SSAP30-505 complete mandible; 1SSAP6-120 and 145 left mandible; 1SSAP6-1, 1SSAP6-24, 1SSAP6-126, 2SSAP30-468, 2SSAP30-674 right mandibles; 2SSAP30-202, 1SSAP6-2, 1SSAP6-9 tusks.

Description. The mandibles are generally brevirostrine, with a short symphysis. Molars display a moderately simple gomphotheriid pattern of enamel folding. When present, $\mathrm{m} 2$ are bunolophodont and $\mathrm{m} 3$ have four-and-a-half to five angular lophs. Opposite pretrite and postrite cusps alternate within the posterior lophs. Facets of wear display simple trefoils. The isolated tusks exhibit a distinctive spiral enamel band. Additional mandibular material, several isolated molars, deciduous premolars and abundant disarticulated postcranial remains are found at Río Tomayate; many still lie in plaster jackets. All these materials are likely to belong to Cuvieronius. All proboscidean material from Río Tomayate has been recovered from the lower bonebed.

Remarks. It seems evident, from the size disparity in the sample, that there is a large sexual dimorphism in Cuvieronius from Río Tomayate. Mandible 2SSAP30-44 and 45, here considered a female, belongs to a small individual of advanced 


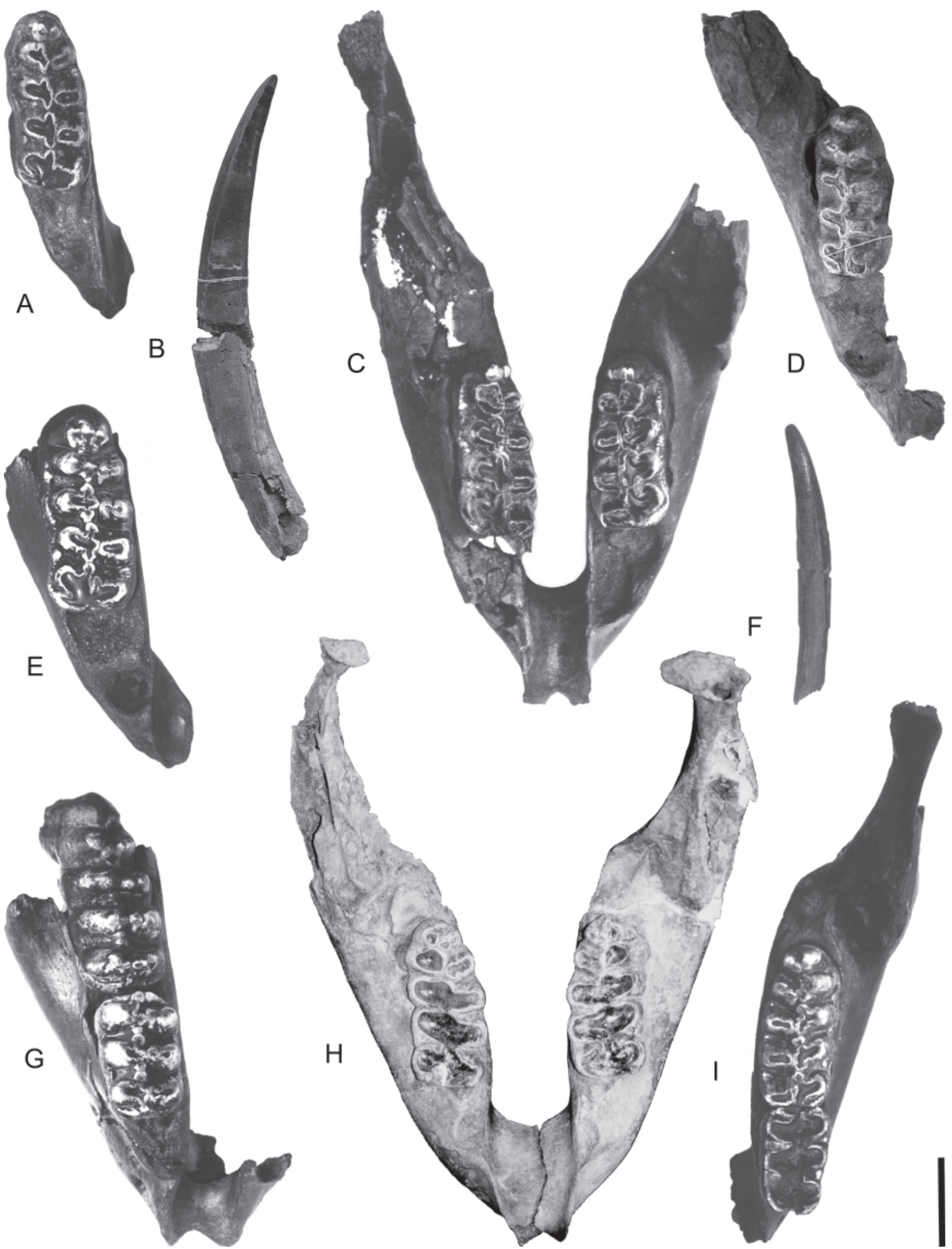

Figure 6. The proboscidean Cuvieronius tropicus from Río Tomayate. A, 2SSAP30-468 partial right mandible; B, 1SSAP6-2 tusk; C, 2SSAP30-593 mandible; D, 1SSAP6-1 right mandible; E, 2SSAP30-674 partial right mandible; F, 1SSAP6-9 tusk; G, 1SSAP6-126 partial right mandible; H, 2SSAP30-44 and 45 mandible; I, 1SSAP6-120 and 145 left mandible. All mandibles are in occlusal view. Scale bar $=100 \mathrm{~mm}$. 

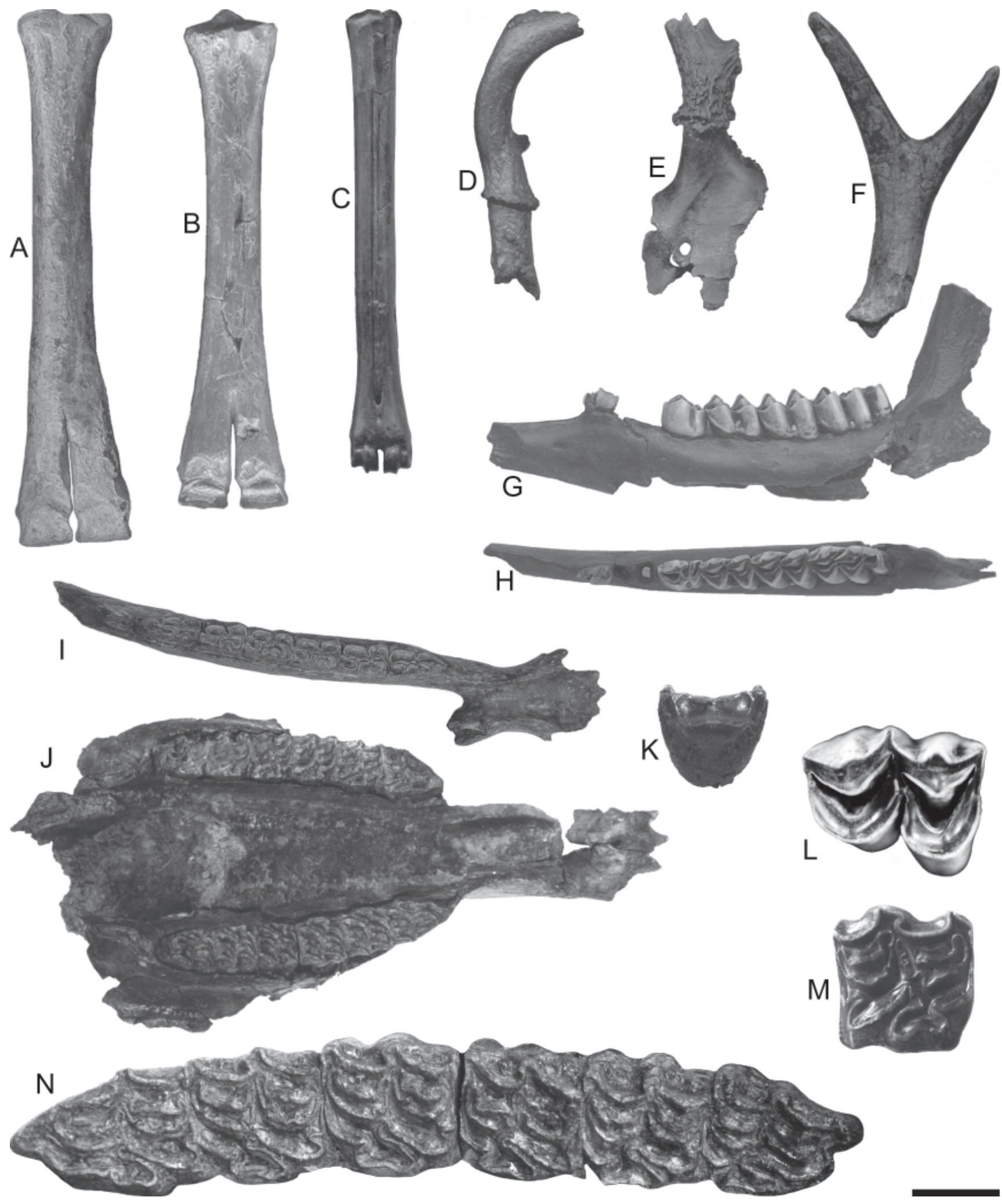

Figure 7. Artiodactyls and equids from Río Tomayate. A, B, 1SSAP6-144 Palaeolama sp., A, metacarpus in posterior view and B, metatarsus in anterior view; C, 2SSAP30-482 Mazama sp. metatarsus in anterior view; D, 2SSAP30-843 Odocoileus cf. O. virginianus, left antler; E, 2SSAP30-792 Odocoileus cf. O. virginianus, left antler and frontal bone in dorsal view, F, 2SSAP30-529 Odocoileus cf. O. virginianus, antler; G, 1SSAP6-23 Mazama sp., left mandibular ramus in lateral view; H, 1SSAP6-23 Mazama sp., left mandibular ramus in occlusal view; I, 2SSAP30-109 Equus conversidens, left mandible in occlusal view; J, 2SSAP30-135 Equus conversidens, cranium in palatal view; K, 2SSAP30-887 Equus conversidens, ungual phalanx in dorsal view; L, 2SSAP30-875 Hemiauchenia cf. H. seymourensis, RM3 in occlusal view; M, 2SSAP30-296 Equus conversidens, Lp4 in occlusal view; N, 2SSAP30-135 Equus conversidens, detail of left premaxillary and maxillary dentition. Scale bar is $50 \mathrm{~mm}$ for A-B, I-K; $35 \mathrm{~mm}$ for C-F, $20 \mathrm{~mm}$ for G, H; $17 \mathrm{~mm}$ for M, N; $13 \mathrm{~mm}$ for L. 
age, as indicated by the solely presence of an $\mathrm{m} 3$ heavily worn. This mandible is much smaller than the immature 1SSAP6-126, a massive right ramus in which $\mathrm{m} 1$ has recently fallen, $m 2$ is still present, and $m 3$ has just erupted. Judging by the preserved dimensions of the incomplete 1SSAP6-126, the specimen suggests a male individual some $30 \%$ larger than 2SSAP30-44 and 45. A comparable degree of sexual dimorphism is known to occur in the modern Elephas maximus and Loxodonta africana, as well as in the fossil Mammuthus primigenius and Mammut americanum (Haynes, 1991). Cuvieronius is generally considered to be a "small-sized" proboscidean, nevertheless, the largest remains from Río Tomayate are comparable in size to those of the American mastodon Mammut americanum.

The status of Cuvieronius species in both North and South America is the subject of much nomenclatural debate. Recent authors recognize only one species in the genus, $C$. tarijensis (Ficcarelli et al., 1995) or C. hyodon (Alberdi et al., 2004; Prado et al., 2003, 2005). These authors, however, restricted their discussion to South American material, and ignored North American species. Moreover, the name $C$. tarijensis was erroneously erected as a "new species" by Ficcarelli, and is in fact a nomen nudum (Cabrera, 1929; Hoffstetter, 1952). The species C. hyodon is also problematical. It is based on a single $\mathrm{m} 2$ that could be either referred to Cuvieronius or Stegomastodon (Montellano Ballesteros, 2002). Recently described Mexican material was referred to C. tropicus by Montellano Ballesteros (2002), based on the similarities in morphology and measurements with the holotype. In the same work, this author emphasized the ambiguous differences between $C$. tropicus and the species $C$. oligobunis, also from Mexico, although she did not formally synonymize them. The opinion that $C$. hyodon is a dubious species is endorsed here, and the name $C$. tropicus is preferred due to its name priority over $C$. oligobunis (ICZN, 1999).

Cuvieronius has been previously reported at El Salvador at Río Sisimico (Stirton \& Gealey, 1949; Schmidt-Thomé, 1975; Webb \& Perrigo, 1984), El Hormiguero (Webb \& Perrigo, 1984) and an unidentified locality in La Unión (Stirton \& Gealey, 1949). The genus is also known from several localities in the Pleistocene of Guatemala, Nicaragua, Costa Rica and Panama (Leidy, 1886; Gazin, 1956; Woodburne, 1969; Laurito Mora, 1988; Acuña Mesén \& García Díaz, 1998; Lucas et al., 1999).

PERISSODACTYLA Owen, 1848
EQUIDAE Gray, 1821
Equus Linnaeus, 1758
Equus conversidens Owen, 1869

(Figure 7I-K, M, N)
Referred material. 2SSAP30-135 cranium, 2SSAP30-109 left mandible and 2SSAP30-296 left fourth premolar.

Description. 2SSAP30-135 is a small cranium, the roof and the braincase are heavily weathered, the material is otherwise damaged by the recent intrusion of roots. All molars and premolars are present. No incisors are present, but the alveoli are preserved, as well as the alveolus that accommodated the left canine. 2SSAP30-109 is a partial left mandible, found less than $0.5 \mathrm{~m}$ from the cranium and it is assigned to the same individual. The mandible is also damaged by intrusion of roots mostly located within the meckelian fossa. The ascending ramus is absent, as is the ventral surface of the horizontal ramus. The symphysis area is well preserved, and the entire anterior portion of the right ramus between the $\mathrm{Rm} 2$ and the symphysis is present. All left cheek teeth are preserved, including the canine. Left and right incisors are missing, but their alveoli are preserved, as well as the right canine alveolus. The specimens belong to an adult individual with pronounced wear on upper and lower teeth. 2SSAP30296 is a well-preserved Lp4 of a young individual.

Several dental characters in the Río Tomayate specimens are listed the most common characters found by Reynoso Rosales \& Montellano Ballesteros (1994) within the range of variation of $E$. conversidens specimens from Cedazo, Aguascalientes, Mexico. These include: (i) deep mesometastyle valleys in premolars, but flattened in molars; (ii) prominent parastyles with flattened ends in premolars, and rounded ends in molars; (iii) pli paraconules present; pli caballin present in premolars, absent in molars; (iv) one quarter of the protocone placed anterior to the isthmus; (v) protocone with concave labial border and rounded ends; (vi) linguaflexid in wide "V" shape; (vii) acute metastylid end; (viii) isthmus in lower premolars complete, in lower molars intermediate; and (ix) absence of protostylid (for a discussion of these characters see the aforementioned authors). On this basis, the materials here presented are referred to E. conversidens, the common small horse from the Pleistocene of North America. Isolated postcranial remains are also present at Río Tomayate and these are provisionally referred to $E$. conversidens.

Remarks. The specimens represent the first confirmed report of E. conversidens in Central America, and its southernmost record. There are several reports of Pleistocene Equus remains for Honduras, El Salvador, Nicaragua, Costa Rica and Panama (Leidy, 1886; McGrew, 1942; Gazin, 1956; Espinosa Estrada, 1976; Webb \& Perrigo, 1984; Lucas et al., 1999). However, none was identified at species level, probably because of the fragmentary nature of most records, in addition to the problematical state of Equus nomenclature in North America.

\author{
ARTIODACTYLA Owen, 1848 \\ RUMINANTIA Scopoli, 1777 \\ CERVIDAE Gray, 1821 \\ Odocoileus Rafinesque, 1832 \\ Odocoileus cf. O. virginianus Zimmerman, 1780
}

(Figure 7D-F)

Referred material. 2SSAP30-529, 2SSAP30-792 and 2SSAP30843 antlers.

Description. The specimens were not found in association and represent different individuals. 2SSAP30-792 is the base of a left antler and portion of the frontal bone, in which the dorsal margin of the orbit and the supraoccipital foramen can 
be seen. 2SSAP30-529 is a two-pointed antler and 2SSAP30843 is the base of a left antler. Odocoileus is the only deer known in Central America to posses branched antlers, on this basis, the specimens are assigned to this genus.

Remarks. The specimens represent the first fossil record of the white-tailed deer Odocoileus in El Salvador. No antlers recovered at Río Tomayate have been preserved completely enough to verify the branching pattern that distinguishes the two Odocoileus species. O. virginianus, however, is the only species present in Central America in modern times, with a wide distribution, from Canada to Bolivia, in contrast with the more limited geographic range of the mule deer $O$. hemionus, restricted to western North America. Hence, Odocoileus specimens from Río Tomayate are provisionally referred to Odocoileus cf. O. virginianus. Fossil Odocoileus remains, not identified to species level, have been recovered at Yeroconte, Honduras (Webb \& Perrigo, 1984); El Hatillo, Panama (Gazin, 1956); and El Bosque, Nicaragua (Espinosa Estrada, 1976; Page, 1978).

\section{Mazama Rafinesque, 1817 Mazama sp. \\ (Figure 7C, G, H)}

Description. 1SSAP6-23 is a well-preserved left mandibular ramus of an adult individual, bearing p2, p4-m3 (see Table 1 for measurements). The area of the symphysis is missing as is most of the ventral surface of the dentary. Most of the coronoid process is present, but the mandibular condyle and the angular process are missing. In labial view, the mental foramen can be seen close to the p2. The specimen 2SSAP30482 is a well-preserved adult right metatarsus (maximum measurements: length, $199 \mathrm{~mm}$; width of proximal head, 25 $\mathrm{mm}$; width of distal head, $26 \mathrm{~mm}$ ).

Discussion. This represents the first non-dubious fossil record of the red brocket deer in Central America. Identification of the specimens from Rio Tomayate as Mazama relies mainly on their measurements. These belong to adult individuals, as indicated by the presence of permanent dentition and fused epiphyses; they are smaller than the same elements in female Odocoileus, but comparable to those in female or male Mazama individuals. The remains, however, do not allow a specific identification. Interestingly, there are no historical records of the genus Mazama in El Salvador, except for

TABLE 1. Maximum measurements (in $\mathrm{mm}$ ) of Mazama left mandibular ramus (1SSAP6-23) from Río Tomayate.

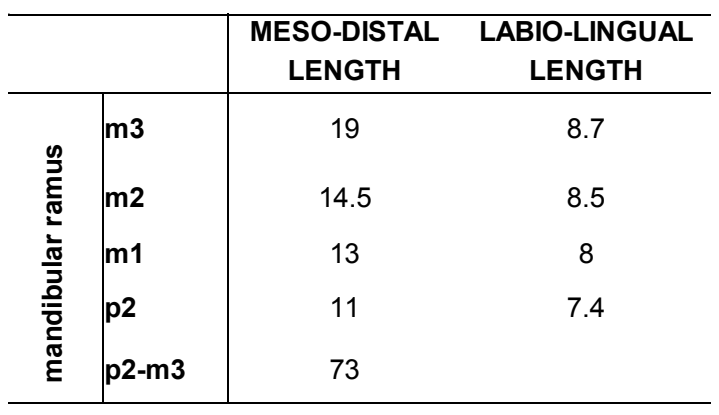

exceptional sightings in altitude forests close to the border with Honduras and Guatemala (Ricardo Ibarra, pers. comm.). Mazama material from the Late Pleistocene site at Santa Amelia, in Guatemala, cited by Woodburne (1969) were based on Barnum Brown's field notes and should be considered unconfirmed.

\author{
TYLOPODA Illiger, 1811 \\ CAMELIDAE Gray, 1821 \\ Palaeolama Gervais, 1867 \\ Palaeolama sp. \\ (Figure 7A, B)
}

Referred material. 1SSAP6-144 a metatarsus and a metacarpus.

Description. These metapodial elements found in association, posses comparable dimensions and presumably belong to the same individual. The metacarpus maximum length is 309 $\mathrm{mm}$, its proximal maximum width is $50 \mathrm{~mm}$ and its distal maximum width is $64 \mathrm{~mm}$. The metatarsus maximum length is $287 \mathrm{~mm}$, its proximal maximum width is $53 \mathrm{~mm}$ and its distal maximum width is $63 \mathrm{~mm}$. Among Pleistocene llamas, relatively short and robust proportions are indicative of Palaeolama (Menégaz \& Jaureguizar, 1995; Webb \& Stehli, 1995).

Remarks. These materials represent the first report of the genus Palaeolama in Central America. Llama material from Río Tomayate also includes some isolated teeth, and presumably several postcranial elements, not listed here. Taking into account the geographical position of El Salvador, the occurrence at Río Tomayate either of the North American P. mirifica or the South American P. weddelli seems equally parsimonious. According to Webb \& Stehli (1995) the specimens of $P$. weddelli from the Middle Pleistocene Tarija deposits in southern Bolivia, differ mainly in being significantly larger than P. mirifica from the Lower Pleistocene Leisey Shell Pits of Florida, USA. When comparing measurements of 1SSAP6-144 with figured metapodials from both species (in Boule \& Thevenin, 1920; Webb \& Stehli, 1995), the Río Tomayate material shows to be much larger than P. mirifica, and even larger than P. weddelli. Nevertheless, the Río Tomayate metapodials are shorter than those of the North American Alforjas, a llama that also possesses robust limbs, and is restricted to the Miocene and Pliocene. Río Tomayate materials can be assigned to the genus Palaeolama, but their specific identification remains uncertain, and it is possible that they represent a new species.

\section{Hemiauchenia Gervais \& Ameghino, 1880 \\ Hemiauchenia cf. H. seymourensis Hibbard \& Dalquest, 1962} (Figure 7L)

Referred material. 2SSAP30-875, right third upper molar. Description. Maximum measurements: meso-distal length, 26.1 $\mathrm{mm}$; labio-lingual length, $21 \mathrm{~mm}$. This molar is distinguished from Palaeolama due to its prominent hypsodonty, a typical character of Hemiauchenia (Webb \& Stehli, 1995). The tooth is larger than the average $\mathrm{M} 3$ of $H$. macrocephala, indicating 


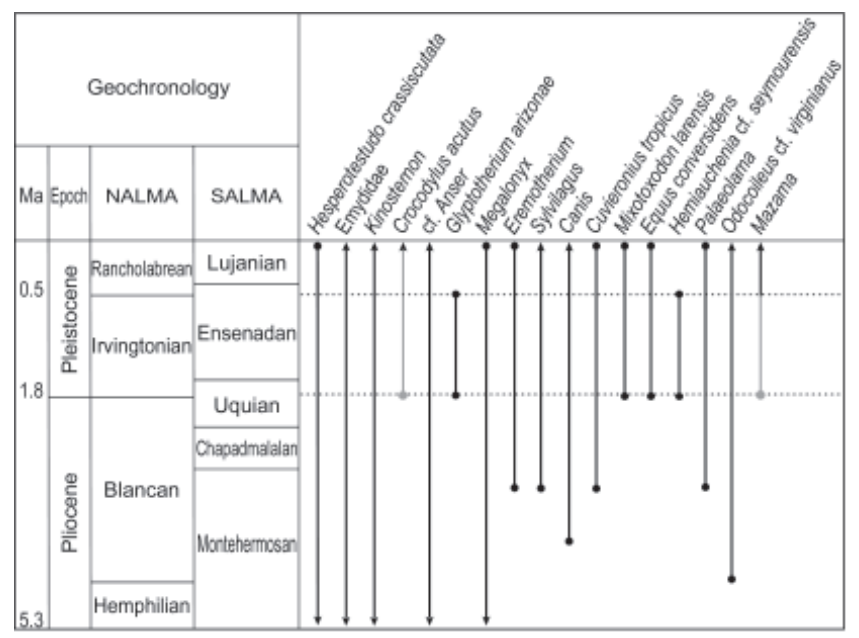

Figure 8. Chronological range in North America of vertebrates from Río Tomayate (from Tedford et al., 1987; Meylan, 1995; Cartelle \& de luliis, 1995; McKenna \& Bell, 1997). The range of Mazama is based on its fossil record from South America (Webb, 2000). Gray lines represent proposed extended lineages for $C$. acutus and Mazama based on this study. Dashed lines delimit the age proposed for the Río Tomayate local fauna, Irvingtonian NALMA.

affinities with $H$. seymourensis or H. blancoensis. Although it may be difficult to differentiate between the Blancan $H$. blancoensis and the Irvingtonian $H$. seymourensis on the basis of a single molar, 2SSAP30-875 is comparable to $H$. seymourensis specimens from the Leisey Shell Pits, both in measurements and in the possession of a heavy layer of cementum that gives $H$. seymourensis "a distinctively blackened and roughened surface” Webb \& Stehli (1995). The presence of Pleistocene-restricted taxa at Río Tomayate (see discussion below) also suggests that $H$. seymourensis rather than $H$. blancoensis is present at the site. The validity of the species $H$. seymourensis, however, has been recently questioned (Hulbert Jr., 2001), thus, the specific identification of the single tooth from Río Tomayate is provisional.

Remarks. This tooth represents the first record of the genus Hemiauchenia in Central America. Additional isolated teeth as well as postcranial remains found at Río Tomayate may be referable to either Hemiauchenia or Palaeolama.

\section{DISCUSSION}

The Tomayate local fauna substantially increases the record of Salvadorian fossil vertebrates. The large concentration of Cuvieronius material so far recovered matches the well known deposits of Tarija, Bolivia, and the seventeen taxa unearthed at Río Tomayate make this new local fauna more diverse than any other vertebrate locality of Central America (Table 2). The potential of the site is high, considering that only a small part of the visible bonebeds has been excavated. In spite of the richness of the new locality, it is remarkable that no small bones have been recovered, even though screen washing was attempted repeatedly. Proboscideans and megatheriids, the largest individuals recorded in the outcrop, are the dominant taxa at Río
Tomayate. In contrast, only one lagomorph bone has been identified, and no rodents or lizardsso far have been found. Webb \& Perrigo (1984) suggested a preservational bias against small vertebrates in Central American outcrops. This may be due to the high-energy nature of the depositional environment, perhaps related to the action of tropical storms, which could act as a selective mechanical control over the preservation of vertebrates in the region. Further work on the taphonomy of deposits such as this is needed to better understand this phenomenon.

Several taxa recovered at Río Tomayate occur across the Plio-Pleistocene boundary and, consequently, cannot be used for a precise correlation. The locality, however, includes taxa whose only confirmed records are in the Pleistocene (Figure 8); these are Glyptotherium arizonae, Mixotoxodon larensis, Equus conversidens and Mazama (Gillette \& Ray, 1980; Reynoso Rosales \& Montellano Ballesteros 1994; McKenna \& Bell, 1997; Lucas et al., 1999; Webb, 2000). A Pleistocene age is also supported indirectly by the presence of Crocodylus acutus, an extant taxon with no previously confirmed fossil record. At present, no typical Rancholabrean taxa have been recovered at Río Tomayate. On the other hand, the presence of Hemiauchenia cf. H. seymourensis and Glyptotherium arizonae points to Irvingtonian NALMA (Webb \& Stehli, 1995; Gillette \& Ray, 1980). As discussed above, the distinction between the species $H$. seymourensis from $H$. blancoensis, based on a single molar, may not be conclusive. However, none of these llamas reaches the Rancholabrean NALMA, and consequently they support an older age for Río Tomayate, which cannot be Blancan due to the presence of taxa restricted to the Pleistocene.

The recognition of an Irvingtonian NALMA for the Río Tomayate fauna leads to a comparison with the neighboring Río Sisimico fauna (see location in Figure 1B), the only other relatively well-known Central American fauna for which this age has been proposed (Webb \& Perrigo, 1984, 1985). The main argument these authors used for assigning an Early to Middle Pleistocene age to Río Sisimico was the primitive morphology of the endemic megalonychids Meizonyx salvadorensis and Megalonyx obtusidens. As discussed above, Megalonyx molariforms found at Río Tomayate cannot be assigned to $M$. obtusidens; consequently, they are not useful for establishing a correlation between these local faunas. If the faunas of Río Tomayate and Río Sisimico were contemporaneous, the resultant assemblage would represent an unusual case of three megalonychid species living closely (the sites are some $50 \mathrm{~km}$ from each other). Río Sisimico and Río Tomayate share the presence of Hesperotestudo, Eremotherium, Mixotoxodon larensis and Cuvieronius tropicus. All four taxa are present in several Pleistocene Central American faunas (Table 2). Furthermore, the three mammals Eremotherium, Mixotoxodon and Cuvieronius tropicus are also found in association at El Hormiguero, El Salvador and El Chorro, Nicaragua; both are Rancholabrean localities (Stirton \& Gealey, 1949; Leidy, 1886). There is insufficient evidence to assess whether the local faunas of Río Sisimico and Río Tomayate were strictly contemporaneous. 
Table 2. The most representative Pleistocene local faunas of continental vertebrates in Central America (sites with four or more identified taxa) based on literature (Álvarez \& Aguilar, 1957; Czaplewski et al., 2003; Espinoza Estrada, 1976; Gazin, 1956; Leidy, 1886; Lucas et al., 1999; Mook, 1959; Page, 1978; Reshetov, 1982; Rosen \& Bailey, 1967; Seiffert, 1977; Stirton \& Gealey, 1949; Webb, 1991; Webb \& Perrigo, 1984, 1985; Woodburne, 1969) and this study. Abbreviations: C, Cebada Cave, Belize, Late Pleistocene-Holocene; SA, Santa Amelia, Guatemala, Late Pleistocene; S, Río Sisimico (also Barranca del Sisimico or Sisimite), El Salvador, Early-Middle Pleistocene; T, Río Tomayate, El Salvador, Early Pleistocene; H, El Hormiguero, El Salvador, Late Pleistocene; Y, Yeroconte, Honduras, Late Pleistocene, Honduras; HU, Río Humuya, Honduras, Late Pleistocene; B, El Bosque, Nicaragua, Late Pleistocene; CH, Río El Chorro, Nicaragua, Pleistocene; BH, Barra Honda, Costa Rica, Pleistocene; HA, El Hatillo, Panama, Late Pleistocene. Except for Dicotyles tajacu and Crocodylus moreletti, that were formally described, the faunal list from Santa Amelia must be considered provisional. The genus name Stegomastodon is used here instead of Haplomastodon following Prado et al. (2003, 2005).

\begin{tabular}{|c|c|c|c|c|c|c|c|c|c|c|c|}
\hline (2) & $\mathbf{C}$ & SA & $\mathbf{S}$ & $T$ & $\mathbf{H}$ & $\mathbf{Y}$ & HU & \multirow[t]{2}{*}{ B } & \multicolumn{3}{|c|}{ CH BH HA } \\
\hline Teleostei & & & & & & & & & & & \\
\hline Poeciliopsis maldonadoi & & & $x$ & & & & & & & & \\
\hline Poecilia sphenops & & & $x$ & & & & & & & & \\
\hline Anura & & & & & & & & & & & \\
\hline Rana sickenbergi & & & $\mathrm{X}$ & & & & & & & & \\
\hline Cryptodira & & & & & & & & & & & \\
\hline Hesperotestudo sp. & & & $\mathrm{X}$ & & $X$ & & & & & & \\
\hline H. crassiscutata & & & & $x$ & & & & & & & \\
\hline Testudinidae indet. & & & & & & & & $x$ & & & \\
\hline Rhinoclemmys sp. & & & & & & & $\mathrm{X}$ & & & & \\
\hline Pseudemys sp. & & & & & & & & & & & $x$ \\
\hline Emydidae indet. & & & & $x$ & & & & & & & \\
\hline Kinosternon sp. & & & & $x$ & & & & & & & \\
\hline Chelonia indet. & & & & & & & & $x$ & & & \\
\hline Crocodylomorpha & & & & & & & & & & & \\
\hline Crocodylus acutus & & & & $x$ & & & & & & & \\
\hline Anseriformes & & & & & & & & & & & \\
\hline cf. Anser sp. & & & & $x$ & & & & & & & \\
\hline Cairina moschata & & & & & & & & & & & $x$ \\
\hline Xenarthra & & & & & & & & & & & \\
\hline Glyptotherium arizonae & & & & $x$ & & & & & & & \\
\hline Glyptotherium sp. & & & & & $X$ & $x$ & & & & & \\
\hline Glyptodon sp. & & $\mathrm{X}$ & & & & & & & & $x$ & $x$ \\
\hline Hoplophorini indet. & & & & & & & & & & & $?$ \\
\hline Dasypus sp. & & $\mathrm{X}$ & & & & & & & & & \\
\hline Pampatherium sp. & & $?$ & & & & & & & & & \\
\hline Mylodon sp. & & $?$ & & & & & & & & & \\
\hline Paramylodon sp. & & $?$ & & & & & & & & & \\
\hline cf. Glossotherium sp. & & & & & & & & & & & $x$ \\
\hline Scelidotherium sp. & & & & & & & & & & & $?$ \\
\hline Megalonyx obtusidens & & & $x$ & & & & & & & & \\
\hline Meizonyx salvadorensis & & & $x$ & & & & & & & & \\
\hline Megalonyx sp. & & $\mathrm{x}$ & & $\mathrm{X}$ & & & $x$ & & & & \\
\hline Megalonychidae indet. & & & & & & & & $x$ & & & \\
\hline Eremotherium laurillardi & & $x$ & & & $x$ & $x$ & $x$ & $x$ & $\mathrm{X}$ & & $\mathrm{X}$ \\
\hline Eremotherium sp. & & & $x$ & $x$ & & & & & & & \\
\hline Chiroptera & & & & & & & & & & & \\
\hline Pteronotus parnelli & & & $x$ & & & & & & & & \\
\hline Desmodus draculae & $x$ & & & & & & & & & & \\
\hline Tonatia saurophila & $x$ & & & & & & & & & & \\
\hline Carollia sp. & $\mathrm{X}$ & & & & & & & & & & \\
\hline Artibeus lituratus & $x$ & & & & & & & & & & \\
\hline
\end{tabular}

\begin{tabular}{|c|c|c|c|c|c|c|c|c|c|c|}
\hline \multirow{2}{*}{ Chiroptera (cont.) } & \multirow[t]{2}{*}{ SA } & \multirow[t]{2}{*}{$\mathbf{s}$} & \multirow[t]{2}{*}{$\mathbf{T}$} & \multirow[t]{2}{*}{$\mathrm{H}$} & \multirow[t]{2}{*}{$\bar{Y}$} & \multirow{2}{*}{\multicolumn{2}{|c|}{ HU }} & \multicolumn{3}{|c|}{ CH BH HA } \\
\hline & & & & & & & & & & \\
\hline Centurio cenex & $\mathrm{x}$ & & & & & & & & & \\
\hline Sturnira sp. & $x$ & & & & & & & & & \\
\hline Laisurus blossevillii & $x$ & & & & & & & & & \\
\hline Lasiurus ega & $\mathrm{x}$ & & & & & & & & & \\
\hline Carnivora & & & & & & & & & & \\
\hline Felis concolor & & & & & $\mathrm{x}$ & & & & & \\
\hline Felis sp. & $\mathrm{x}$ & & & & & & & & & \\
\hline Smilodon sp. & & & & $\mathrm{x}$ & & & & & & \\
\hline aff. Canis & & & $\mathrm{x}$ & & & & & & & \\
\hline Canis latrans & & & & & & & & & $\mathrm{x}$ & \\
\hline Tremarctos floridanus & $\mathrm{x}$ & & & & & & & & & \\
\hline Proboscidea & & & & & & & & & & \\
\hline Cuvieronius tropicus & ? & $\mathrm{x}$ & $\mathrm{x}$ & $\mathrm{x}$ & & & & $\mathrm{x}$ & & $\mathrm{x}$ \\
\hline Stegomastodon waringi & & & & & & & & & $\mathrm{X}$ & \\
\hline Gomphotheriidae indet. & & & & & $x$ & & $\mathrm{x}$ & & & \\
\hline Mammuthus sp. & & & & & & & & $\mathrm{x}$ & & \\
\hline Mammuthus cf. columbi & & & & & & $\mathrm{x}$ & & & & \\
\hline Notoungulata & & & & & & & & & & \\
\hline Mixotoxodon larensis & $?$ & $\mathrm{x}$ & $x$ & $x$ & $\mathrm{x}$ & $x$ & ? & $\mathrm{x}$ & & \\
\hline Perissodactyla & & & & & & & & & & \\
\hline Equus sp. & & & & $x$ & $x$ & $\mathrm{x}$ & & $\mathrm{x}$ & $x$ & $\mathrm{x}$ \\
\hline E. conversidens & & & $\mathrm{x}$ & & & & & & & \\
\hline Equidae indet. & $\mathrm{x}$ & & & & & & $\mathrm{x}$ & & & \\
\hline Tapirus sp. & $\mathrm{x}$ & & & & & & & & & \\
\hline Artiodactyla & & & & & & & & & & \\
\hline Camelops sp. & & & & & $\mathrm{x}$ & & & & & \\
\hline Palaeolama sp. & & & $\mathrm{x}$ & & & & & & & \\
\hline $\begin{array}{r}\text { Hemiauchenia cf. } \\
\text { seymourensis }\end{array}$ & & & $\mathrm{x}$ & & & & & & & \\
\hline Camelidae indet. & $x$ & & & $x$ & & & & & & \\
\hline Odocoileus sp. & & & & & $\mathrm{x}$ & & $\mathrm{x}$ & & & $\mathrm{x}$ \\
\hline O. cf. virginianus & & & $\mathrm{x}$ & & & & & & & \\
\hline Mazama sp. & ? & & $\mathrm{x}$ & & & & & & & \\
\hline Cervidae indet. & & $\mathrm{x}$ & & & & & & & & \\
\hline Tayassu tajacu & $\mathrm{x}$ & & & & & & & & & \\
\hline Tayassuidae indet. & & & & & & & & & & \\
\hline Bison sp. & ? & & & $\mathrm{x}$ & & & & $\mathrm{x}$ & & \\
\hline Rodentia & & & & & & & & & & \\
\hline Neochoerus pinckneyi & & & & $\mathrm{x}$ & & & & $\mathrm{x}$ & & $\mathrm{x}$ \\
\hline Hydrochoerus sp. & $\mathrm{x}$ & & & & & $\mathrm{X}$ & & & & \\
\hline Lagomorpha & & & & & & & & & & \\
\hline Sylvilagus sp. & & & $\mathrm{X}$ & & & $\mathrm{x}$ & & & & \\
\hline
\end{tabular}

No other local fauna in Central America or in the neighbouring Mexico and Colombia resembles that of Río Tomayate. For instance, the record of Palaeolama represents an isolated record between southern USA and Venezuela (alleged Palaeolama remains from central Mexico were transferred to Hemiauchenia sp. by Montellano, 1989). Likewise, the molar of Hemiauchenia reported from the new site represents the sole report of this genus between central Mexico and Bolivia. Some of the North American taxa present at the new site did not apparently cross the Panamanian isthmus during the GAFI, as was the case for Equus

conversidens and Glyptotherium arizonae, with their southernmost record at Río Tomayate. These taxa have not yet been found at other Central American localities. Megalonyx, also present at Río Tomayate, has no confirmed records in South America. On the other hand, there are no confirmed fossil discoveries of Mazama and toxodontids north of El Salvador and Guatemala, respectively (but see Polaco et al., 2004 for a preliminary toxodontid report in central Mexico). No South American faunas, Ensenadan or Uquian, seem to be comparable to the new site. Only Irvingtonian local faunas resemble Río Tomayate. For the Irvingtonian 
Gilliland Local Fauna, Texas, USA, Hibbard \& Dalquest (1966) report six taxa that are present at Río Tomayate: a "large" Hesperotestudo (presumably H. crassiscutata), G. arizonae, Cuvieronius tropicus, Sylvilagus, Hemiauchenia seymourensis and Odocoileus. The local fauna most readily comparable to Río Tomayate, however, is probably the Leisey Shell Pits in Florida, USA (early Irvingtonian NALMA, Morgan \& Hulbert Jr., 1995). The taxa common to Río Tomayate include Kinosternon, Hesperotestudo crassiscutata, Glyptotherium arizonae, Eremotherium, Cuvieronius tropicus, Sylvilagus, Odocoileus, Hemiauchenia seymourensis and Palaeolama. This faunal similarity supports an Irvingtonian NALMA for Río Tomayate.

The record of Mazama at Río Tomayate is significant. Except for an unconfirmed report in the Upper Pleistocene of Guatemala (Woodburne, 1969; see Table 2), there are no fossil records of Mazama in Central America or elsewhere in North America. However, this genus is present in the Upper Pleistocene of Brazil (de Paula Couto, 1980). Besides being the only non-dubious fossil record of Mazama outside South America, the material from Río Tomayate is also the oldest, supporting a Central American origin for this genus, a hypothesis previously proposed by Webb (2000).

The current absence of both Palaeolama and Hemiauchenia in the fossil record of other Central American countries is notorious. This may be considered a result of the lack of systematic prospecting in the area. However, isolated Pleistocene records are common in the region, specially those of Late Pleistocene age. Lardé-yLarín (1950) reported some 30 such sites for El Salvador, and Lucas et al. (1999) listed a similar number of these sites for Costa Rica. A more intriguing hypothesis would be that Palaeolama and Hemiauchenia may have become extinct in Central America in the Late Pleistocene, explaining, thus, the current absence of fossils of these llamas from sites of younger age than Río Tomayate in the region. Except for Río Sisimico in El Salvador, and the small locality of Bajo Barrantes in Costa Rica that only yielded Mixotoxodon larensis (Laurito Mora, 1993; Lucas et al., 1999), all well correlated Pleistocene sites in Central America are younger than Río Tomayate. Clearly more prospecting in the region is necessary to assess this hypothesis. At present, it is not clear if Palaeolama is a taxon that evolved in North America or in South America. The first appearance datum on both continents has a similar age, early Irvingtonian NALMA (Webb \& Stehli, 1995) and Uquian SALMA (Marshall et al., 1984; Mones, 1988) respectively. The record of this genus at Río Tomayate raises a third possibility, that Palaeolama evolved in Central America and dispersed in both directions.

The presence of large tortoises such as Hesperotestudo crassiscutata, is usually seen as an indicator of more xeric environments than at present (Preston, 1979; Hulbert Jr. \& Pratt, 1998), a possibility also supported by the record of camelidsin Río Tomayate. In El Salvador, a dry environment would be more likely during a glacial stage.

\section{CONCLUSIONS}

Río Tomayate is so far the richest vertebrate locality known in Central America and probably the largest known concentration of Cuvieronius in America. Crocodylus acutus has now fossil record, whereas Equus conversidens and Glyptotherium arizonae have their geographical ranges extended to Central America. The records of Palaeolama and Hemiauchenia eliminate "gaps" in the distribution of these fossil mammals in America. The age of the fauna is probably Early to Middle Pleistocene, as suggested by the overall similarity with North American Irvingtonian faunas, as well as the presence of $H$. cf. $H$. seymourensis and $G$. arizonae. A precise correlation with the nearby Río Sisimico local fauna, however, remains uncertain, due to the lack of shared index taxa. The first appearance datum of Mazama from Río Tomayate provides support to the hypothesis that this genus evolved in Central America and dispersed to South America. Some taxa, in particular Hesperotestudo crassiscutata, are indicative of an arid, perhaps colder environment for El Salvador at the time of accumulation of these fossils.

\section{ACKNOWLEDGMENTS}

Special thanks to Teófilo Reyes for discovering the superb fossils of Río Tomayate, and to his brother Francisco, for the permission and facilities to work on his property. Both are also acknowledged for their dedicated work in the field. Special thanks are due to Leticia Escobar, José Santos and Alejandra González at Taller de Restauración of Museo Nacional de Antropología, for their valuable advice and skillful work on fossil preparation and conservation. Marisol Montellano Ballesteros and an anonymous reviewer are acknowledged for valuable comments on the manuscript. Carmen Tamacas is acknowledged for supplementary photography and Federico Hernández at Consejo Nacional para la Cultura y el Arte (CONCULTURA) is recognized for the permission to examine additional specimens under his care. Alfredo Zurita, Francisco Prevosti, Ricardo Negri, Edio E. Kischlat and Víctor H. Reynoso Rosales are recognized for their valuable assistance on the identification of a number of taxa. Spencer G. Lucas, Norma L. Nasif, Graciela I. Esteban, Ana M. Ribeiro, Fernando Abdala and Patrícia H. Rodrigues are acknowledged for general discussion. Robin Pickering is recognized for her geological advice. The author is grateful to US Peace Corps for providing volunteers for fossil preparation. Álex Perla is acknowledged for volunteer fieldwork and preparation, and D. Aguilar and M. Romero for assistance in the field. The author received a grant from Palaeontological Scientific Trust (PAST), in South Africa. Part of this study was carried out by the author at MUHNES-CONCULTURA during 2001 and 2002.

\section{REFERENCES}

Acuña Mesén, R. \& García Díaz, E. 1998. Nuevo ejemplar de Cuvieronius hyodon (Proboscidea: Gomphotheriidae) del 
Pleistoceno de Costa Rica. Revista de Biología Tropical, 46:1167-1172.

Alberdi, M.T.; Prado, J.L. \& Salas, R. 2004. The Pleistocene Gomphotheriidae (Proboscidea) from Peru. Neues Jahrbuch für Geologie und Paläontologie, Abhandlungen, 231(3):423452.

Álvarez, J. \& Aguilar, F. 1957. Contribución al estudio de la suspensión gonopódica del género Poeciliopsis con descripción de una nueva especie fósil procedente de El Salvador, Centro America. Revista de la Sociedad Mexicana de Historia Natural, 18:153-172.

Auffenberg, W. 1963. Fossil testudinine turtles of Florida. Genera Geochelone and Floridemys. Bulletin of the Florida State Museum, 7:53-97.

Boule, M. \& Thevenin, A. 1920. Mammifères fossiles de Tarija. Paris, Imprimerie Nationale, 255 p., 27 pls.

Cabrera, A. 1929. Una revisión de los mastodontes Argentinos. Revista del Museo de La Plata, 32:61-144.

Cartelle, C. \& de Iuliis. G. 1995. Eremotherium laurillardi: The Panamerican Late Pleistocene megatheriid sloth. Journal of Vertebrate Paleontology, 15:830-841.

Czaplewski, N.C.; Krejca, J. \& Miller, T.E. 2003. Late Quaternary bats from Cebada Cave, Chiquibul Cave System, Belize. Caribbean Journal of Science, 39:23-33.

Espinosa Estrada, J. 1976. Excavaciones arqueológicas en "El Bosque”. Instituto Geográfico Nacional, Managua, 76 p. (Informe 1)

Ficcarelli, G.V.; Borselli, V.; Herrera, G.; Moreno Espinoza, M. \& Torre. D. 1995. Taxonomic remarks on the South American mastodons referred to Haplomastodon and Cuvieronius. Geobios, 28:745-756.

van Frank, R. 1957. A fossil collection from northern Venezuela, 1. Toxodontidae (Mammalia, Notoungulata). American Museum Novitates $1850,38 \mathrm{p}$.

Gazin, C.L. 1956. Exploration for the remains of giant ground sloths in Panama. Annual Report of the Board of Regents of the Smithsonian Institution, 4272:341-354.

Gillette, D.D. \& Ray, C.E. 1981. Glyptodonts of North America. Smithsonian Contributions to Paleobiology 40, 255 p.

Hay, O.P. 1922. Further observations on some extinct elephants. Proceedings of the Biological Society of Washington, 35:97101.

Haynes, G. 1991. Mammoths, mastodons, and elephants: Biology, behavior, and the fossil record. Cambridge, Cambridge University Press, $413 \mathrm{p}$.

Hibbard, C.W. \& Dalquest, W.W. 1966. Fossils from the Seymour Formation of Knox and Baylor counties, Texas, and their bearing on the Late Kansan climate of that region. Contributions from the Museum of Paleontology, The University of Michigan, 21(1):1-66.

Hoffstetter, R., 1952. Les mammifères Pléistocenes de la République de l'Equateur. Mémoires Société Gélogique de France, 66, 1391.

Howell, T.R. 1969. A Pleistocene vertebrate fauna from Nicaragua. Special Papers of the Geological Society of America, 121:143144.

Hulbert Jr. R.C. (ed) 2001. The fossil vertebrates of Florida. University Press of Florida, $384 \mathrm{p}$.

Hulbert Jr. R.C. \& Pratt, A.E. 1998. New Pleistocene (Rancholabrean) vertebrate faunas from coastal Georgia. Journal of Vertebrate Paleontology, 18:412-429.

ICZN (International Commission on Zoological Nomenclature) 1999.
International Code of Zoological Nomenclature. International Trust for Zoological Nomenclature, London, $306 \mathrm{p}$.

de Iuliis, G. \& Cartelle, C. 1999. A new giant megatheriine ground sloth (Mammalia: Xenarthra: Megatheriidae) from the late Blancan to early Irvingtonian of Florida. Zoological Journal of the Linnean Society, 127:495-515.

Laurito Mora, C.A. 1988. Los proboscídeos fósiles de Costa Rica y su contexto en la América Central. Vínculos, 14:29-58.

Laurito Mora, C.A. 1993. Análisis topológico y sistemático del toxodonte de los Barrantes, provincia de Alajuela, Costa Rica. Revista Geológica de América Central, 11:41-50.

Lardé-y-Larín, J. 1950. Índice provisional de las regiones fosilíferas de El Salvador. Anales del Museo Nacional David J. Guzmán, 1:68-74.

Leidy, J. 1886. Toxodon and other remains from Nicaragua. Proceedings of the Academy of Natural Sciences of Philadelphia (unnumbered volume):275-277.

Lucas, S.G. \& Alvarado, G.E. 1991. El hallazgo más austral de un Mammut americanum, el caso del mastodonte de San Pedro Sula, Honduras. Revista Geológica de América Central, 13:8589.

Lucas, S.G. \& Alvarado, G.E. 1994. The role of Central America in land vertebrate dispersal during the late Cretaceous and Cenozoic. Profil 7:401-412.

Lucas, S.G. \& Alvarado, G.E. 1995. El proboscideo Rhyncotherium blicki (Mioceno Tardío) del oriente de Guatemala. Revista Geológica de América Central, 18:19-24.

Lucas, S.G.; Alvarado, G.E. \& Vega, E. 1999. The Pleistocene mammals of Costa Rica. Journal of Vertebrate Paleontology, 17:413-427.

Marshall, L.G.; Berta, A.; Hoffstetter, R.; Pascual, R.; Reig, O.A.; Bombin, M. \& Mones, A. 1984. Mammals and stratigraphy: Geochronology of the continental mammal-bearing Quaternary of South America. Palaeovertebrata, Mémorie Extraordinaire, $76 \mathrm{p}$.

McGrew, P.O. 1942. Field Museum paleontological expedition to Honduras. Science, New Series, 96:85.

McKenna, M.C. \& Bell. S.K. 1997. Classification of mammals; above the species level. New York, Columbia University Press, $640 \mathrm{p}$.

Menégaz, A.N. \& Jaureguizar, E.O. 1995. Los artiodáctilos. In: M.T. Alberdi, G. Leone \& E.P. Tonni (eds.) Evolución biológica y climática de la región pampeana durante los últimos cinco millones de años. Madrid, Museo Nacional de Ciencias Naturales, Consejo Superior de Investigaciones Científicas, p. 311-337

Meylan, P.A. 2000. Hesperotestudo (Testudines: Testudinidae) from the Pleistocene of Bermuda, with comments on the phylogenetic position of the genus. Zoological Journal of the Linnean Society, 128:51-76.

Meylan, P.A. 1995. Pleistocene amphibians and reptiles from the Leisey Shell Pit, Hillsborough County, Florida. Bulletin of the Florida Museum of Natural History, 37 Pt. 1(9):273-297.

Mones, A. 1988. Notas paleontológicas uruguayas IV; nuevos registros de mamíferos fósiles de la Formación San José (Plioceno¿Pleistoceno Inferior?) (Mammalia: Xenarthra; Artiodactyla; Rodentia). Comunicaciones Paleontológicas del Museo de Historia Natural de Montevideo, 20:255-278.

Montellano, M. 1989. Pliocene camelidae of Rancho El Ocote, Central Mexico. Journal of Mammology, 70:359-369.

Montellano Ballesteros, M. 1999. Intercambio biótico terrestre entre Norte y Sud América. GEOS, Boletín Informativo de la 
Unión Geofísica Mexicana, A. C, 3:179-186.

Montellano Ballesteros, M. 2002. New Cuvieronius finds from the Pleistocene of Central Mexico. Journal of Paleontology, 76:578-583.

Mook, C.C. 1959. A new Pleistocene crocodilian from Guatemala. American Museum Novitates 1975, 6 p.

Morgan, G.S. \& Hulbert Jr. R.C. 1995. Overview of the geology and vertebrate biochronology of the Leisey Shell Pit Local Fauna, Hillsborough County, Florida. Bulletin of the Florida Museum of Natural History, 37 Pt. 1(1):1-92.

Neill, W.T. 1971. The last of the ruling reptiles: alligators, crocodiles, and their kin. New York, Columbia University Press, 486 p.

Page, W.D. 1978. The geology of El Bosque Archaeological Site, Nicaragua. In: Early Man in America from a Circum-Pacific Perspective. Occasional Papers of the Department of Anthropology, University of Alberta, p. 231-260 (Number 1).

de Paula Couto, C. 1980. Mamíferos fósseis do Pleistoceno de Jacupiringa, Estado de São Paulo. Anais da Academia Brasileira de Ciências, 52:135-141.

Polaco, O.J.; Guzmán, A.F. \& Ramírez, G.T. 2004. Presencia de toxodontes en el Pleistoceno de México. In: IX CONGRESO NACIONAL DE PALEONTOLOGÍA, 2004. Libro de Resúmenes, Tuxtla Gutiérrez, p. 50.

de Porta, J. 1959. Nueva subespecie de toxodóntido del Cuaternario de Colombia. Boletín de Geología de la Universidad Industrial de Santander, 3:55-61.

Prado, J.L.; Alberdi, M.T.; Azanza, B.; Sánchez, B. \& Frassinetti, D. 2005. The Pleistocene Gomphotheriidae (Proboscidea) from South America. Quaternary International, 126-128:21-30.

Prado, J.L.; Alberdi, M.T.; Sánchez, B.\& Azanza, B. 2003. Diversity of the Pleistocene Gomphotheres (Gomphotheriidae, Proboscidea) from South America. Deinsea, 9:347-363.

Preston, R.E. 1979. Late Pleistocene cold-blooded vertebrate faunas from the mid-continental United States; I. Reptilia; Testudines, Crocodilia. University of Michigan Museum of Paleontology, Papers on Paleontology 19, 53 p.

Reshetov, V.J. 1982. Reporte preliminar sobre la observación de la paleontología en Nicaragua. Unpublished report on file at the Palaeontological Institute, Russian Academy of Sciences, 13 p. [Spanish translation from original in Russian]

Reynoso Rosales, V.H. \& Montellano Ballesteros, M. 1994. Revisión de los équidos de la fauna Cedazo del Pleistoceno de Aguascalientes, México. Revista Mexicana de ciencias Geológicas, 11:87-105.

Rosen, D.E. \& Bailey, R.M. 1963. The poeciliid fishes (Cyprinodontiformes), their structure, zoogeography, and systematics. Bulletin of the American Museum of Natural History, 126:1-176 p.

Schmidt-Thomé, M. 1975. The Geology in the San Salvador area (El Salvador, Central America), a basis for city development and planning. Geologisches Jahrbuch, B13:207-228.
Seiffert, J. 1977. Fossile Frösche (Diplasiocoela Noble 1931) aus einer Kieselgur von El Salvador. Geologisches Jahrbuch, B23:2945.

Simpson, G.G. 1980. Splendid isolation. New Haven, Yale University Press, $266 \mathrm{p}$.

Simpson, G.G. \& de Paula Couto, C. 1957. The mastodonts of Brazil. Bulletin of the American Museum of Natural History, 112:125-190.

Smith, J. B. \& Dodson, P. 2003. A proposal for a standard terminology of anatomical notation and orientation in fossil vertebrate dentitions. Journal of Vertebrate Paleontology, 23:112.

Stirton, R.A. \& Gealey, W.K. 1949. Reconnaissance geology and vertebrate paleontology of El Salvador, Central America. Geological Society of America Bulletin, 60:1731-1764.

Tedford, R.H.; Skinner, M.F.; Fields, R.W., Rensberger, J.M.; Whistler, D.P.; Galisha, T.; Taylor, B.E.; Macdonald, J.R. \& Webb, S.D. 1987. Faunal succession and biochronology of the Arikareean through Hemphillian interval (late Oligocene through earliest Pliocene epochs) in North America. In: M.O. Woodburne (ed.) Cenozoic Mammals of North America. Geochronology and Biostratigraphy. University of California Press, p. 153210 .

Webb, D.S. 1991. Ecogeography and the Great American Interchange. Paleobiology, 17:266-280.

Webb, D.S. 1997. The Great American Faunal Interchange. In: A.G. Coates (ed.) Central America: A natural and cultural history. Yale University Press, p. 97-122.

Webb, D.S. 2000. Evolutionary history of the New World Cervidae. In: E.S. Vrba \& G. B. Schaller (eds.) Antelopes, deer, and relatives; fossil record, behavioral ecology, systematics, and conservation. Yale University Press, p. 38-64.

Webb, D.S. \& Perrigo, S. 1984. Late Cenozoic vertebrates from Honduras and El Salvador. Journal of Vertebrate Paleontology, 4:237-254.

Webb, D.S. \& Perrigo, S. 1985. New megalonychid sloths from El Salvador. In: G.G. Montgomery (ed.) The Evolution and Ecology of Armadillos, Sloths, and Vermilinguas. Washington, Smithsonian Institution Press, p. 113-120

Webb, D.S. \& Stehli, F.G. 1995. Selenodont artiodactyla (Camelidae and Cervidae) from the Leisey Shell Pits, Hillsborough County, Florida. Bulletin of the Florida Museum of Natural History, 37 Part 2 (19):621-643.

Whitmore, F.C. Jr. \& Stewart, R.H. 1965. Miocene mammals and Central American seaways. Science, 148:180-185.

Woodburne, M.O. 1969. A Late Pleistocene occurrence of the collared peccary, Dicotyles tajacu, in Guatemala. Journal of Mammology, 50:121-125.

Received August, 2005; accepted October, 2005. 